\title{
Nitrate dynamics in natural plants: insights based on the concentration and natural isotope abundances of tissue nitrate
}

\author{
Xue-Yan Liu ${ }^{1,2 *}$, Keisuke Koba ${ }^{2}$, Akiko Makabe ${ }^{2}$ and Cong-Qiang Liu' ${ }^{1}$ \\ 1 State Key Laboratory of Environmental Geochemistry, Institute of Geochemistry, Chinese Academy of Sciences, Guiyang, China \\ ${ }^{2}$ Department of Environmental Science on Biosphere, Institute of Agriculture, Tokyo University of Agriculture and Technology, Fuchu, Japan
}

\section{Edited by:}

Jan Kofod Schjoerring, University of

Copenhagen, Denmark

\section{Reviewed by:}

Kristian Holst Laursen, University of Copenhagen, Denmark

Benton N. Taylor, Columbia

University, USA

${ }^{*}$ Correspondence:

Xue-Yan Liu, State Key Laboratory of Environmental Geochemistry, Institute of Geochemistry, Chinese Academy of Sciences, 46 Guanshui Road, Guiyang, Guizhou Province 550002, China

e-mail: liuxueyan@vip.skleg.cn
The dynamics of nitrate $\left(\mathrm{NO}_{3}^{-}\right)$, a major nitrogen $(\mathrm{N})$ source for natural plants, has been studied mostly through experimental $\mathrm{N}$ addition, enzymatic assay, isotope labeling, and genetic expression. However, artificial $\mathrm{N}$ supply may not reasonably reflect the $\mathrm{N}$ strategies in natural plants because $\mathrm{NO}_{3}^{-}$uptake and reduction may vary with external $\mathrm{N}$ availability. Due to abrupt application and short operation time, field $\mathrm{N}$ addition, and isotopic labeling hinder the elucidation of in situ $\mathrm{NO}_{3}^{-}$-use mechanisms. The concentration and natural isotopes of tissue $\mathrm{NO}_{3}^{-}$can offer insights into the plant $\mathrm{NO}_{3}^{-}$sources and dynamics in a natural context. Furthermore, they facilitate the exploration of plant $\mathrm{NO}_{3}^{-}$ utilization and its interaction with $\mathrm{N}$ pollution and ecosystem $\mathrm{N}$ cycles without disturbing the $\mathrm{N}$ pools. The present study was conducted to review the application of the denitrifier method for concentration and isotope analyses of $\mathrm{NO}_{3}^{-}$in plants. Moreover, this study highlights the utility and advantages of these parameters in interpreting $\mathrm{NO}_{3}^{-}$sources and dynamics in natural plants. We summarize the major sources and reduction processes of $\mathrm{NO}_{3}^{-}$in plants, and discuss the implications of $\mathrm{NO}_{3}^{-}$concentration in plant tissues based on existing data. Particular emphasis was laid on the regulation of soil $\mathrm{NO}_{3}^{-}$and plant ecophysiological functions in interspecific and intra-plant $\mathrm{NO}_{3}^{-}$variations. We introduce $\mathrm{N}$ and $\mathrm{O}$ isotope systematics of $\mathrm{NO}_{3}^{-}$in plants and discuss the principles and feasibilities of using isotopic enrichment and fractionation factors; the correlation between concentration and isotopes ( $\mathrm{N}$ and $\mathrm{O}$ isotopes: $\delta^{18} \mathrm{O}$ and $\Delta^{17} \mathrm{O}$ ); and isotope mass-balance calculations to constrain sources and reduction of $\mathrm{NO}_{3}^{-}$in possible scenarios for natural plants are deliberated. Finally, we offer a preliminary framework of intraplant $\delta^{18} \mathrm{O}_{-} \mathrm{NO}_{3}^{-}$variation, and summarize the uncertainties in using tissue $\mathrm{NO}_{3}^{-}$parameters to interpret plant $\mathrm{NO}_{3}^{-}$ utilization.

Keywords: atmospheric nitrate, denitrifier method, isotopic enrichment, isotopic fractionation, nitrate reductase, oxygen isotope, plant nitrate, soil nitrogen availability

\section{PLANT NITRATE $\left(\mathrm{NO}_{3}^{-}\right)$IN A NATURAL CONTEXT}

Nitrogen $(\mathrm{N})$ is a key factor in the control of the primary productivity in terrestrial plant ecosystems (Vitousek and Howarth, 1991; LeBauer and Treseder, 2008). Among the N species available to plants, ammonium $\left(\mathrm{NH}_{4}^{+}\right)$is dominant in the inorganic $\mathrm{N}$ of unfertilized soils (Schimel and Bennett, 2004) and atmospheric $\mathrm{N}$ deposition (Stevens et al., 2011). Some plants prefer $\mathrm{NH}_{4}^{+}$(Britto and Kronzucker, 2013) while the roots of a few plants directly absorb organic N (Chapin et al., 1993; Näsholm et al., 2009; Hill et al., 2013). However, nitrate $\left(\mathrm{NO}_{3}^{-}\right)$is an important $\mathrm{N}$ source for all plants because of its versatile functions in both plant nutrition and physiological regulations (Raven, 2003; Wang et al., 2012). The utilization of $\mathrm{NO}_{3}^{-}$(mainly uptake and reduction/assimilation) has been investigated intensively in plants through characterization of related enzymes including nitrate reductase (NR) and nitrite reductase (NiR) and their activities (NRA and NiRA, respectively) in response to different environmental conditions (Beevers and Hageman, 1969; Atkin et al., 1993; Kronzucker et al., 1995; Campbell, 1999). The framework of plant $\mathrm{NO}_{3}^{-}$studies has expanded in the past few decades due to the availability of molecular techniques. A few model plants have been used in understanding the transporters responsible for $\mathrm{NO}_{3}^{-}$uptake and transportation (Wang et al., 2012). Besides its function in nutrient supply, plant $\mathrm{NO}_{3}^{-}$and its metabolism contain unique information related to the mediation of plant physiology, diversity, and the ecosystem $\mathrm{N}$ cycle (Crawford, 1995; Tischner, 2000). However, evolution has yielded diverse strategies by which plants acquire $\mathrm{N}$ and $\mathrm{NO}_{3}^{-}$from natural environments to adapt to changes in ecosystem $\mathrm{N}$ availability (Chapin, 1980; Raven and Yin, 1998; Nacry et al., 2013). Therefore, there are considerable uncertainties in assessing the utilization of $\mathrm{NO}_{3}^{-}$by plants in natural habitats, which cannot be explained fully by laboratory-based mechanisms because of methodological constraints. Consequently, a great need exists 
for a straightforward estimation of plant $\mathrm{NO}_{3}^{-}$availability and a mechanistic understanding of the processes controlling plant $\mathrm{NO}_{3}^{-}$uptake and reduction. These can enhance our understanding of the role of plant $\mathrm{NO}_{3}^{-}$utilization in the ecosystem $\mathrm{N}$ cycle and the changes of plant growth and diversity with ecosystem $\mathrm{N}$ status (Lambers et al., 2008; Bloom et al., 2010; Boudsocq et al., 2012).

\section{DENITRIFIER METHOD FOR $\mathrm{NO}_{3}^{-}$IN NATURAL PLANTS}

Natural abundance of stable isotopes in natural plants can integrate the information related to $\mathrm{N}$ sources and physiological processes (Högberg, 1997; Robinson, 2001; Craine et al., 2009). The stable isotopes include $\delta^{15} \mathrm{~N}, \delta^{18} \mathrm{O}$, and $\delta^{17} \mathrm{O}$ for $\mathrm{NO}_{3}^{-} ;{ }^{15} \mathrm{~N}:{ }^{14} \mathrm{~N}$, ${ }^{18} \mathrm{O}:{ }^{16} \mathrm{O}$, and ${ }^{17} \mathrm{O}:{ }^{16} \mathrm{O}$ ratios expressed relative to atmospheric $\mathrm{N}_{2}$ and standardized mean ocean water (VSMOW), respectively (Coplen, 2011). These isotopes have been broadly used for studying plant $\mathrm{N}$ strategies and enzymatic dynamics in natural settings (Evans, 2001; Tcherkez and Farquhar, 2006; Granger et al., 2010). Nevertheless, it is difficult to measure the concentration and isotopes $\left(\delta^{15} \mathrm{~N}\right.$ and $\left.\delta^{18} \mathrm{O}\right)$ of $\mathrm{NO}_{3}^{-}$in plant tissues precisely using traditional methods (Liu et al., 2012a). The use of the denitrifier method for measuring low (sub-nanomole) concentrations of $\mathrm{NO}_{3}^{-}\left(\left[\mathrm{NO}_{3}^{-}\right]\right)$started during the mid-1980s (Lensi et al., 1985). The method has high sensitivity and is especially applicable for samples with low $\left[\mathrm{NO}_{3}^{-}\right]$but with high dissolved organic carbon (DOC) (Christensen and Tiedje, 1988; Binnerup and Sørensen, 1992; Aakra et al., 2000). The denitrifier method developed for both $\delta^{15} \mathrm{~N}$ and $\delta^{18} \mathrm{O}$ analysis is based on the isotopic analysis of nitrous oxide $\left(\mathrm{N}_{2} \mathrm{O}\right)$. The $\mathrm{N}_{2} \mathrm{O}$ is converted from sample $\mathrm{NO}_{3}^{-}$by cultured denitrifying bacteria (Pseudomonas aureofaciens; ATCC 13985) that lack $\mathrm{N}_{2} \mathrm{O}$ reductase activity (Sigman et al., 2001; Casciotti et al., 2002). The method was initially performed on seawater with $20-50 \mathrm{nmol} \mathrm{NO}_{3}^{-}$. Since then, the application has been expanded widely to accommodate isotopic analysis of $\mathrm{NO}_{3}^{-}$ in fresh water (e.g., groundwater, stream water, precipitation), soil and sediment water, soil extracts, as well as dissolved organic $\mathrm{N}(\mathrm{DON})$ in seawater and DON bound to diatoms as described by Koba et al. (2010a) and McIlvin and Casciotti (2011), respectively. This method has recently been used for measurements of $\mathrm{NO}_{3}^{-}$in natural plants and crops (Liu et al., 2012a, 2013a; Laursen et al., 2013; Bloom et al., 2014; Mihailova et al., 2014). The established protocol facilitates the $\Delta^{17} \mathrm{O}\left(\Delta^{17} \mathrm{O}=\left[1+\delta^{17} \mathrm{O}\right] /\right.$ $\left[1+\delta^{18} \mathrm{O}\right]^{0.5247}-1$; Kaiser et al., 2007) analysis of leaf $\mathrm{NO}_{3}^{-}$ to diagnose atmosphere-derived $\mathrm{NO}_{3}^{-}$in leaf uptake (Mukotaka, 2014).

The denitrifier method enables more precise measurements of subnanomole amounts of $\mathrm{NO}_{3}^{-}$(Binnerup and Sørensen, 1992; Højberg et al., 1994) as compared to traditional methods that use flow injection analysis, ion chromatography, high-performance liquid chromatography, and Kjeldahl distillation. Thus, the denitrifier method overcomes the difficulties in determining $\mathrm{NO}_{3}^{-}$ in plant, soil, and sediment samples (Norwitz and Keliher, 1986; Anderson and Case, 1999; Alves et al., 2000). Moreover, it greatly simplifies the pretreatment procedures and reduces the risk of contamination during plant $\mathrm{NO}_{3}^{-}$isotopic analysis (see the old $\delta^{15} \mathrm{~N}$ protocol in Volk et al., 1979 and Evans et al., 1996). The denitrifier method especially avoids the influence of DOC in plant extracts (Haberhauer and Blochberger, 1999) on the $\delta^{18} \mathrm{O}$ of $\mathrm{NO}_{3}^{-}$ (Figure 1) that was previously measured as carbon monoxide with TC/EA-IRMS (Michalski, 2010).

Compared with NRA assays, concentrations and isotopic signatures of tissue $\mathrm{NO}_{3}^{-}$provide more authentic evidence related to $\mathrm{NO}_{3}^{-}$uptake and reduction under in situ $\mathrm{N}$ availability. In vitro and in vivo NRA measurements (Stewart et al., 1992, 1993) do not reflect the in situ ability of plant $\mathrm{NO}_{3}^{-}$reduction. This is because firstly, the added amount of $\mathrm{NO}_{3}^{-}$(often at the micromolar level) during NRA assays is uniform. Moreover it is much higher than normal $\mathrm{NO}_{3}^{-}$availability and the endogenous $\mathrm{NO}_{3}^{-}$ in natural plants. The synthesis of the NR enzyme or the activation of NRA, however, is substrate-inducible (Beevers and Hageman, 1969; Somers et al., 1983; Campbell, 1999). Secondly, the reagents used in the assay can affect the estimation of NRA. Different analytical settings (e.g., with or without ethanol) can alter the fluxes of $\mathrm{NO}_{3}^{-}$and photosynthate, resulting in different estimations (Ferrari and Varner, 1970; Aslam, 1981). Thirdly, NRA might be altered by $\mathrm{pH}$ adjustment and vacuum infiltration during the NRA analysis. High DOC concentrations in the plant extract also easily destroy the precision of the colorimetric determination of $\mathrm{NO}_{3}^{-}$or nitrite $\left(\mathrm{NO}_{2}^{-}\right)$(Alves et al., 2000).

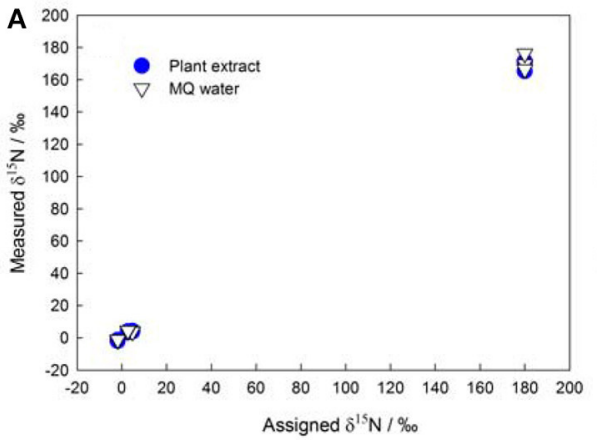

FIGURE 1 | Assigned isotopic ratios (A: $\delta^{15} \mathrm{~N}$; $\mathrm{B}: \delta^{18} \mathrm{O}$ ) of $\mathrm{NO}_{3}^{-}$ standards (IAEA NO${ }_{3}$, USGS-32, USGS-34, and USGS-35) shown against corresponding isotope values measured in MO (Millipore)

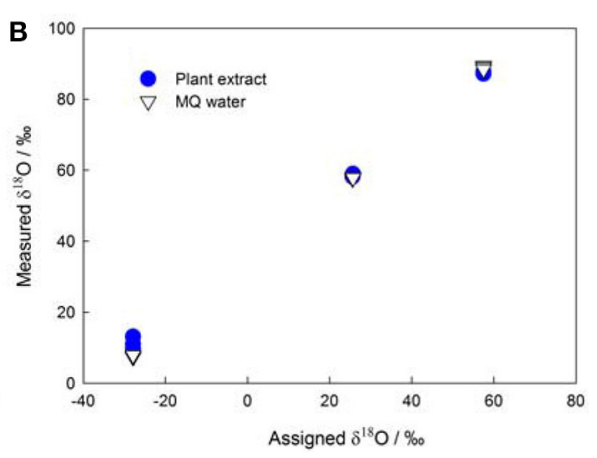

water and in plant extracts (the initial $\mathrm{NO}_{3}^{-}$in plant extracts was removed using the same protocol as that described in Liu et al., 2012a). 
Since natural isotope analysis does not require artificial $\mathrm{N}$ addition, it presents no risk of changing the soil $\mathrm{N}$ pools and plant $\mathrm{N}$-uptake kinetics (Liu et al., 2012b). The natural abundance approach does not disturb the $\mathrm{N}$ pools in plants and provides information related to the $\mathrm{NO}_{3}^{-}$behavior in plant tissues based on isotopic compositions and fractionations. In fact, the field application of ${ }^{15} \mathrm{NO}_{3}^{-}$tracer is advantageous in terms of the total and short-term incorporation of $\mathrm{NO}_{3}^{-}$into plants (e.g., McKane et al., 2002; Wanek and Zotz, 2011). However, the added tracer cannot bypass the influence of soil microbial activity, which can greatly change the picture of $\mathrm{N}$ uptake and preference over time (Harrison et al., 2007). Measurements of cytosolic and vacuolar $\mathrm{NO}_{3}^{-}$concentrations have been conducted to explore factors controlling uptake, intracellular transport and assimilation. However, related techniques such as compartmental radiotracer (e.g., ${ }^{13} \mathrm{~N}$; Kronzucker et al., 1995), efflux analysis, nuclear magnetic resonance, cell fractionation, and $\mathrm{NO}_{3}^{-}$-selective microelectrodes showed high cost and low field operability (Zhen et al., 1991; Miller and Smith, 1996). The calculated $\left[\mathrm{NO}_{3}^{-}\right]$is especially sensitive to the small error of the estimation of cytosolic and vacuolar volumes, the precisions of which are difficult to ascertain.

\section{MAJOR SOURCES AND PROCESSES OF NO- IN NATURAL PLANTS}

Root $\mathrm{NO}_{3}^{-}$uptake from the soil is achieved by active transportation (Wang et al., 2012). The extracellular $\mathrm{NO}_{3}^{-}$enters the cytosol of plant cells where it is either reduced by $\mathrm{NR}_{3}$ to $\mathrm{NO}_{2}^{-}$or stored in the vacuoles (Figure 2). The $\mathrm{NO}_{2}^{-}$will be transported into plastids (in root) or chloroplasts (in leaf) and reduced further by $\mathrm{NiR}$ to reduced N (Figure 2). Both NRA and NiRA are well known to be substrate-inducible, meaning that the de novo synthesis of the enzyme results from the presence and increase of the $\mathrm{NO}_{3}^{-}$ in plants (Beevers and Hageman, 1969; Campbell, 1999). The induction of NRA by both soil and airborne $\mathrm{NO}_{3}^{-}$is an important mechanism to elucidate the interactions among $\mathrm{NO}_{3}^{-}$uptake, translocation/allocation, and reduction dynamics (Norby et al., 1989; Scheible et al., 1997a; Tischner, 2000).

The $\mathrm{NO}_{3}^{-}$transported by the xylem flow, either directly from soil or partially processed by root $\mathrm{NR}$, is the initial $\mathrm{NO}_{3}^{-}$reaching leaves and shoots (Peuke et al., 2013). This is especially true for plants growing at some pristine sites (e.g., arctic tundra) where the atmospheric $\mathrm{NO}_{3}^{-}$availability is negligible. However, in regions with substantial $\mathrm{NO}_{3}^{-}$deposition, both atmospheric $\mathrm{NO}_{\mathrm{x}}$ and $\mathrm{NO}_{3}^{-}$serve as potential sources of $\mathrm{NO}_{3}^{-}$in leaves (Wellburn, 1990; Raven and Yin, 1998; Sparks et al., 2001), especially for nonvascular plants such as mosses, which rely more on atmospheric nutrients (Liu et al., 2012c). Leaf $\mathrm{NO}_{3}^{-}$acquisition from the atmosphere is conducted through passive diffusion mechanisms wherein uptake through the stomata is dominant (Wellburn, 1990; Raven et al., 1992; Gessler et al., 2002) (Figure 2). The leafaccessible $\mathrm{NO}_{3}^{-}$in the atmosphere includes an array of inorganic and organic ions and compounds (Wellburn, 1998; Teklemariam and Sparks, 2004; Vallano and Sparks, 2008). Although, previous tracer studies have described their incorporation into leaves (Hanson and Garten, 1992; Yoneyama et al., 2003; Lockwood et al., 2008), it is rather difficult to apply the natural abundance method for estimating field contributions of atmospheric $\mathrm{NO}_{3}^{-}$. This can be attributed to the heterogeneity in chemical and deposition forms, and temporal and spatial distributions (Sievering et al., 2007; Sparks, 2009).

\section{CONCENTRATION LEVELS AND IMPLICATIONS OF $\mathrm{NO}_{3}^{-}$IN NATURAL PLANTS}

Nitrate cannot be produced in photoautotrophic plants, except in a few legumes (Hipkin et al., 2004). The presence of $\mathrm{NO}_{3}^{-}$in any part of a plant constitutes evidence of $\mathrm{NO}_{3}^{-}$uptake by the plant and reflects that external $\mathrm{NO}_{3}^{-}$is available; and that the rate of uptake is higher than the rate of reduction. The $\mathrm{NO}_{3}^{-}$that is extractable from a plant organ is often a sum of the amounts from the extracellular pool, cytosolic pool, and vacuolar pool (Figure 2). These pool sizes and turnover rates are regulated by both environmental and physiological factors (Zhen et al., 1991; Miller and Smith, 1996), which determine the isotopic signatures of the extracted $\mathrm{NO}_{3}^{-}$. Generally, the concentration level and distribution of $\mathrm{NO}_{3}^{-}$in vascular plants and the variations among species is a complex result of two important factors: external availability (previously often evaluated through $\mathrm{NO}_{3}^{-}$concentration and net nitrification rate in soil) and physiological strategies (mainly including uptake, translocation, and reduction dynamics). Moreover, the external factors also consider the availability of $\mathrm{NO}_{3}^{-}$relative to $\mathrm{NH}_{4}^{+}$or other $\mathrm{N}$ sources because it can influence both plant $\mathrm{NO}_{3}^{-}$uptake and assimilation (Boudsocq et al.,

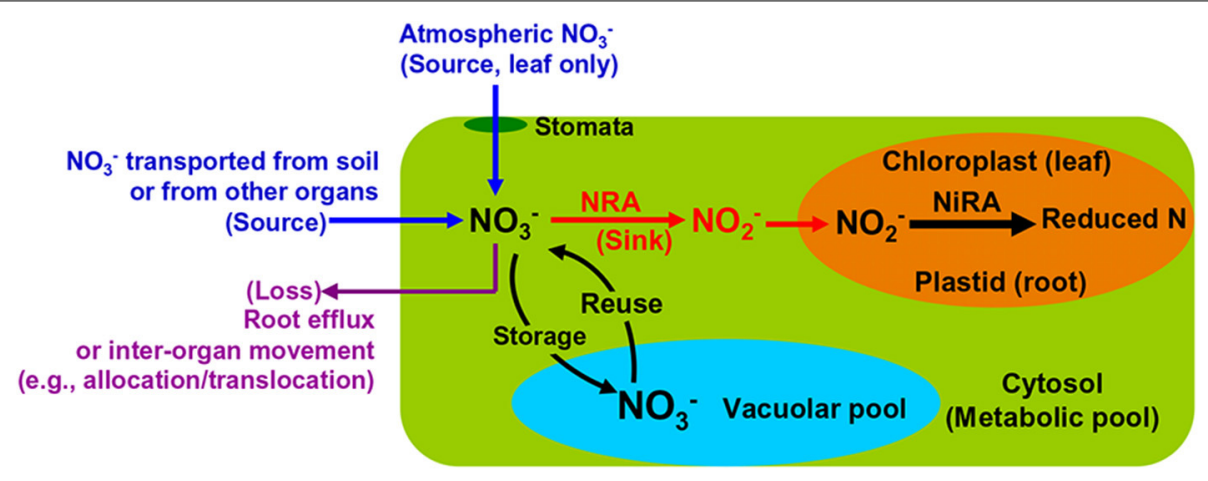

FIGURE 2 | Schematic map showing major $\mathrm{NO}_{3}^{-}$sources and processes in leaves and roots of natural plants. 
2012; Liu et al., 2012c; Britto and Kronzucker, 2013) while the physiological factors include the affinity of plants to different soil $\mathrm{NO}_{3}^{-}$levels (Wang et al., 2012; Kalcsits and Guy, 2013).

First, the distribution of organ-specific $\mathrm{NO}_{3}^{-}$concentrations among plants under different growing conditions (Figures 3, 4A) showed that plants growing in natural soils might also have a high $\mathrm{NO}_{3}^{-}$accumulation. In natural forests, leaf $\mathrm{NO}_{3}^{-}$concentrations of some species can be as high as $1000-10000 \mu \mathrm{g}-\mathrm{N} \mathrm{g}^{-1} \mathrm{dw}$ (Figure 4A; Gebauer et al., 1988; Koyama et al., 2013), which was even higher than those of some crops (e.g., Bloom et al., 2014) and $\mathrm{N}$-polluted natural plants (Figure 3). Plant $\mathrm{NO}_{3}^{-}$concentrations are indicators or predictors of the soil $\mathrm{N}$ cycle (e.g., soil nitrification and soil $\mathrm{NO}_{3}^{-}$) and forest $\mathrm{N}$ pollution (Stams and Schipholt, 1990; Aber et al., 1998; Fenn and Poth, 1998; Koba et al., 2003). Such concentrations show higher sensitivities than bulk $\mathrm{N}$ and NRA parameters in revealing species-level responses to $\mathrm{N}$ enrichment (Fenn et al., 1996; Jones et al., 2008; Tang et al., 2012). The increase in $\mathrm{NO}_{3}^{-}$concentration in roots and or leaves with external $\mathrm{NO}_{3}^{-}$was observed under both natural soil conditions and experimental $\mathrm{N}$ addition (e.g., Stewart et al., 1993; Lexa and Cheeseman, 1997; Wang and Schjoerring, 2012). However, the level of leaf $\mathrm{NO}_{3}^{-}$and its response to soil $\mathrm{NO}_{3}^{-}$variation differ among species with distinct uptake or accumulation rates. For example, the $\mathrm{NO}_{3}^{-}$concentrations in plants (mostly as mosses) we recently investigated (Liu et al., 2012a,c, 2013a) were much lower than those reported by Gebauer et al. (1988) or Koyama et al. (2013) on vascular plants (Figure 4A) when compared within a similar soil $\left[\mathrm{NO}_{3}^{-}\right]$range (e.g., $0-15 \mathrm{mg}-\mathrm{N} \mathrm{kg}^{-1}$ soil, $\mathrm{dw}$ ). Besides, the correlation between leaf $\mathrm{NO}_{3}^{-}$and soil $\mathrm{NO}_{3}^{-}$is apparent for plants with low $\mathrm{NO}_{3}^{-}$concentrations (Figure 4A). However, synthesis or extrapolation to different plants with distinct $\mathrm{NO}_{3}^{-}$

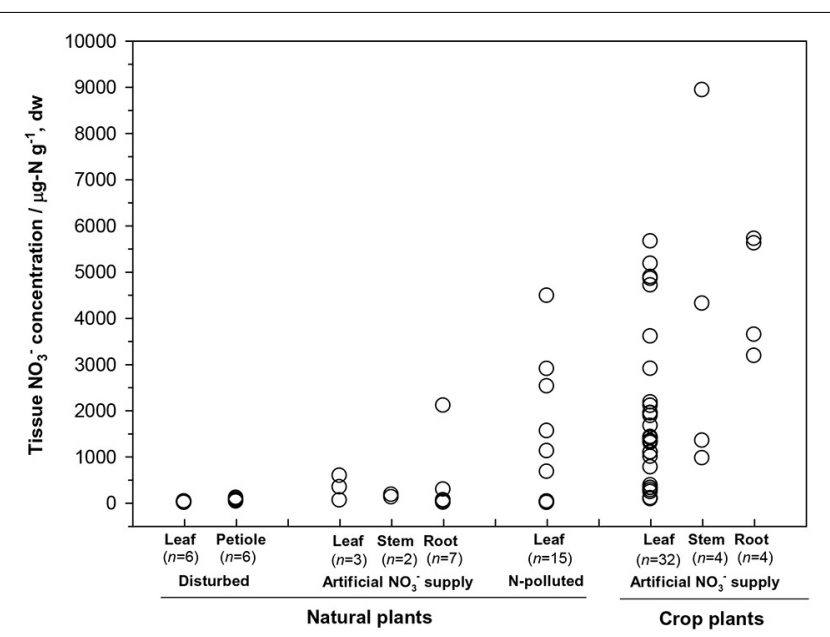

FIGURE 3 | Tissue $\mathrm{NO}_{3}^{-}$concentrations in natural plants growing under disturbed conditions (acidic irrigation and liming; Gebauer et al., 1988), in N-polluted forest plants (Stams and Schipholt, 1990), in natural and crop plants with artificial $\mathrm{NO}_{3}^{-}$supply (data of natural plants were cited from Gebauer et al., 1984; Stadler and Gebauer, 1992; Robe et al., 1994; Simon et al., 2014. Data of crop plants were cited from Evans et al., 1996; Yoneyama and Tanaka, 1999; Prasad and Chetty, 2008 and references cited therein). accumulation abilities should be done carefully when evaluating soil $\mathrm{N}$ enrichment or $\mathrm{N}$ saturation.

Second, considerable differences (up to $4-5$ orders) exist in the level of $\mathrm{NO}_{3}^{-}$among plant organs and species (Figures 3, 4A). The organ-specific patterns of $\mathrm{NO}_{3}^{-}$accumulation among coexisting plants can differ with soil $\mathrm{N}$ availability and the plant growing stage (Gebauer et al., 1984; Stewart et al., 1993; Liu et al., 2013a). However, this has complicated the use and selection of proper organs and species to evaluate ecosystem $\mathrm{N}$ availability based on tissue $\mathrm{NO}_{3}^{-}$analysis. McKane et al. (2002) used ${ }^{15} \mathrm{~N}$ tracers in the field to show that $\mathrm{NO}_{3}^{-}$uptake in the tundra plants did not passively follow external availability, but depended on specific ecophysiological traits. $\mathrm{NO}_{3}^{-}$preference in Carex was determined by the appearance of ${ }^{15} \mathrm{~N}$ tracer in Carex biomass, which showed that the $\mathrm{NO}_{3}^{-}$preference might reflect only the ${ }^{15} \mathrm{NO}_{3}^{-}$-acquiring efficiency associated with root traits, but not $\mathrm{NO}_{3}^{-}$assimilation given significantly lower NRA in Carex than in other species (Nadelhoffer et al., 1996). Therefore, additional studies should be conducted to determine the extent of organspecific and species-specific variability of $\mathrm{NO}_{3}^{-}$concentration that reflects plant $\mathrm{NO}_{3}^{-}$strategy, and the heterogeneity of $\mathrm{NO}_{3}^{-}$available to roots. The available data for natural plants revealed a clear increase in $\mathrm{NO}_{3}^{-}$concentration with bulk $\mathrm{N}$ while a decrease with $\mathrm{C} / \mathrm{N}$ (a clear turning at the $\mathrm{C} / \mathrm{N}$ of 20-30) in different organs or tissue types (Figure 4B). Similarly, Zhen and Leigh (1990) reported that shoot $\mathrm{NO}_{3}^{-}$accumulated as a linear function of bulk $\mathrm{N}$ in wheat plants once a threshold $\mathrm{N}$ was exceeded. These results reflected the regulation of overall physiological $\mathrm{N}$ demand on the $\mathrm{NO}_{3}^{-}$utilization in natural plants (Imsande and Touraine, 1994). The regulation might be unidirectional because the contribution of $\mathrm{NO}_{3}^{-}$to bulk $\mathrm{N}$ assimilation appears to be much lower than that for other $\mathrm{N}$ forms in plants (portrayed in Figure 4B). The complexity of the mutual regulations behind the inverse relation between $\mathrm{NO}_{3}^{-}$and $\mathrm{C} / \mathrm{N}$ might be comparable with the multi-scale inverse relation prevailing between $\mathrm{NO}_{3}^{-}$and organic $\mathrm{C}$ observed in different ecosystems (Taylor and Townsend, 2010). So far, little direct and simple evidence has been obtained for the driving mechanisms of $\mathrm{C}$ and $\mathrm{N}$ metabolism on $\mathrm{NO}_{3}^{-}$uptake, allocation, and accumulation in natural plants. A clearer relation is that even when external $\mathrm{NO}_{3}^{-}$is uniform, the $\mathrm{NO}_{3}^{-}$concentration is often higher in organs (especially for growing leaves) of species with higher NRA than in those with lower NRA (Gebauer et al., 1988; Cruz et al., 1991; Widmann et al., 1993; Min et al., 1998). Mutual induction between the maintenance of high $\mathrm{NO}_{3}^{-}$ concentration and that of NR synthesis or NRA activation were elucidated in view of $\mathrm{C}$ metabolism and $\mathrm{N}$ demand in response to availability and growing conditions (Stewart et al., 1993; Scheible et al., 1997a,b; Scheurwater et al., 2002). The lower $\mathrm{NO}_{3}^{-}$concentration and NRA might be associated with lower $\mathrm{N}$ metabolism and demand in organs and plants with higher $\mathrm{C} / \mathrm{N}$ and vice versa. Therefore, except regulation by soil $\mathrm{NO}_{3}^{-}$concentration, the uptake and distribution of $\mathrm{NO}_{3}^{-}$in a plant might follow the regime of organ-specific or whole-plant metabolic activities.

Other factors such as light and water regimes might also influence plant $\mathrm{NO}_{3}^{-}$accumulation through the pathway of photosynthetic regulation (Widmann et al., 1993; Simon et al., 2014). Cárdenas-Navarro et al. (1999) found concurrent and 


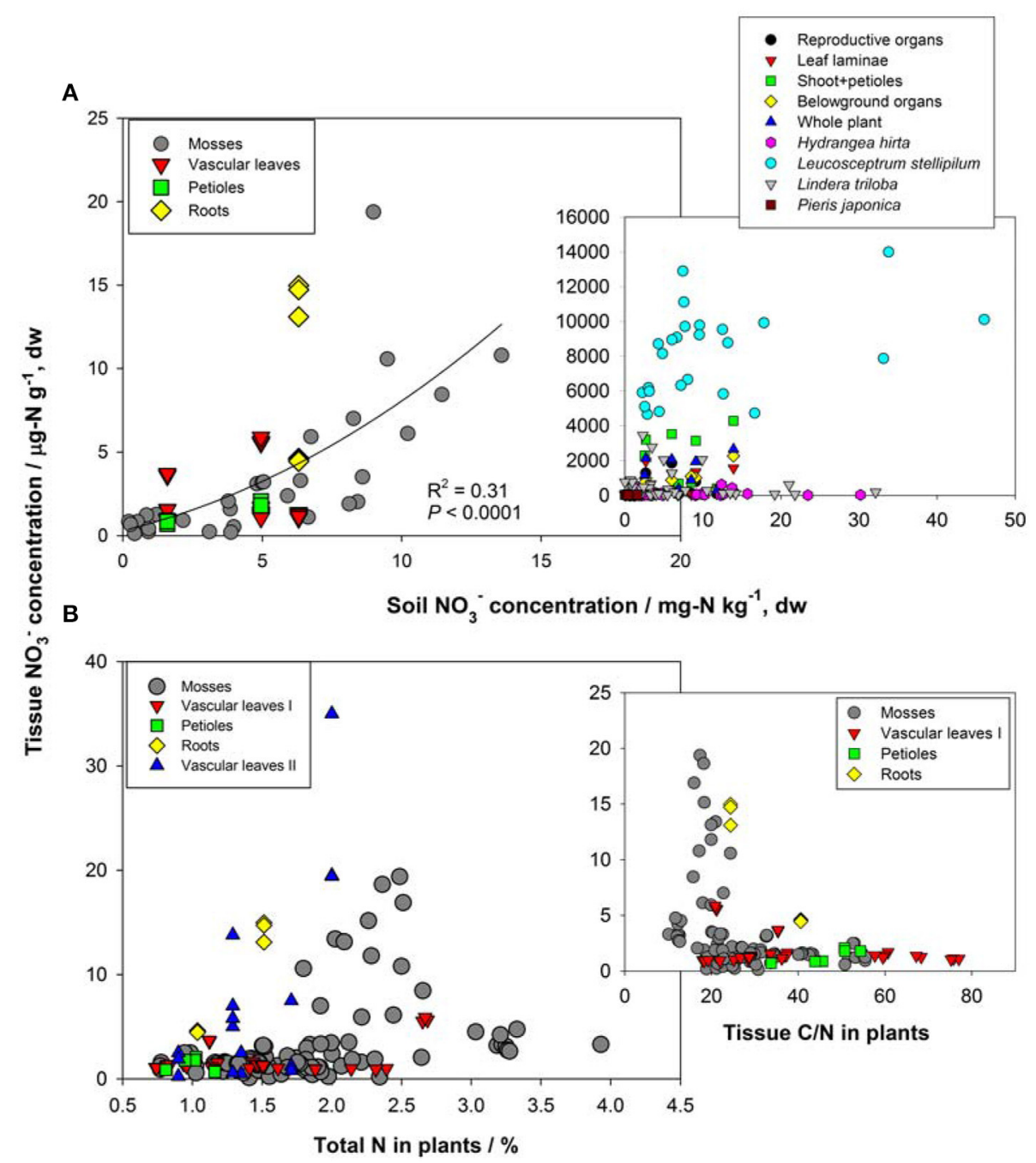

FIGURE 4 | (A) Relation between $\mathrm{NO}_{3}^{-}$concentrations in soil and natural plants. Plant $\mathrm{NO}_{3}^{-}$data in the left panel are shown for individual samples in Guiyang, southwestern China and western Tokyo, Japan reported by Liu et al. (2012a; 2012c, 2013a; 2013b). Plant $\mathrm{NO}_{3}^{-}$data in the right panel show organ-specific and whole-plant concentrations (averages of different species) in ecosystems of Central Europe (see details in Gebauer et al., 1988), and leaf $\mathrm{NO}_{3}^{-}$of different species ( $H$. hirta, P. japonica, L. stellipilum, L. triloba) in a temperate forest of central Japan (Koyama et al., 2013). (B) Relations between total $\mathrm{N}, \mathrm{C} / \mathrm{N}$, and tissue $\mathrm{NO}_{3}^{-}$concentration in natural plants. Mosses include different species in different habitats of Guiyang, Southwestern China, and Western Tokyo, Japan (cited from Liu et al., $2012 a, c)$. Vascular leaves I, petioles and roots were reported for a coniferous and a broadleaved plant in western Tokyo, Japan (cited from Liu et al., 2013a). Vascular leaves II included fern, oak, and pine species at the Camp Paivika and Camp Osceola forest sites in the San Bernardino Mountains of southern California, USA (cited from Fenn et al., 1996). linearly correlated changes in whole-plant $\mathrm{NO}_{3}^{-}$and water content during the day-night cycle, reflecting a homoeostasis effect of endogenous $\mathrm{NO}_{3}^{-}$concentration. Besides, as discussed above, the heterogeneity of soil $\mathrm{NO}_{3}^{-}$available to roots of coexisting species should not be excluded considering the differences in root morphology and spatial distribution. Given the difficulties in determining rhizospheric soil $\mathrm{NO}_{3}^{-}$concentration and flux, it would be promising to measure $\mathrm{NO}_{3}^{-}$concentrations in roots to evaluate $\mathrm{NO}_{3}^{-}$availability to the whole plant or aboveground organs.

\section{ISOTOPIC SYSTEMATICS OF NO- IN PLANTS}

Stable isotopes of $\mathrm{NO}_{3}^{-}$in plants are controlled mainly by $\mathrm{NO}_{3}^{-}$ sources and isotopic effects involved in $\mathrm{NO}_{3}^{-}$acquisition and reduction processes (Robinson et al., 1998; Comstock, 2001; Evans, 2001; Cernusak et al., 2009).

The $\delta^{15} \mathrm{~N}$ of $\mathrm{NO}_{3}^{-}$in soil is reported mostly within -10 to $+10 \%$; however, the $\delta^{15} \mathrm{~N}$ of newly-produced $\mathrm{NO}_{3}^{-}$in soil is usually low because of strong isotopic effects of nitrification, on the other hand, the values can be elevated at sites with marked denitrification (Mariotti et al., 1981; Högberg, 1997; Koba et al., 1998, 2003, 2010b; Houlton et al., 2006; Takebayashi et al., 2010). Atmospheric $\mathrm{NO}_{3}^{-}$has a wider $\delta^{15} \mathrm{~N}$ range $(-15-+15 \%)$ because of its complex production pathways and sources (Heaton, 1990; Felix et al., 2012; Altieri et al., 2013). The $\delta^{15} \mathrm{~N}$ of $\mathrm{NO}_{3}^{-}$ is generally lower in wet than in dry deposition (Heaton et al., 1997; Elliott et al., 2009), but both often show a $\delta^{15} \mathrm{~N}$ range 
overlapping with that of soil $\mathrm{NO}_{3}^{-}$. The $\delta^{18} \mathrm{O}$ of initial $\mathrm{NO}_{3}^{-}$produced in soil is usually estimated using the $\delta^{18} \mathrm{O}$ of in situ $\mathrm{H}_{2} \mathrm{O}$ (normally $-25-4 \%$ ) and atmospheric $\mathrm{O}_{2}$ (ca. 23.5\%0) in a 2:1 ratio, assuming no exchange and fractionation of oxygen $(\mathrm{O})$ isotopes occurs during nitrification and the $\mathrm{NO}_{3}^{-}$is produced solely through chemolithoautotrophic nitrification (Amberger and Schmidt, 1987). However, kinetic isotopic fractionation and $\mathrm{O}$ exchange between $\mathrm{NO}_{2}^{-}$and $\mathrm{H}_{2} \mathrm{O}$ often occur during nitrification, which can eliminate the isotopic signal of $\mathrm{O}_{2}$ effecting lower $\delta^{18} \mathrm{O}$ than the predicted values (Fang et al., 2012). The $\mathrm{O}$ of $\mathrm{NO}_{3}^{-}$in atmospheric deposition is derived mainly from $\mathrm{O}_{2}$ and $\mathrm{O}_{3}$, which have distinctly higher $\delta^{18} \mathrm{O}$ and $\Delta^{17} \mathrm{O}$ signatures than those of soil $\mathrm{NO}_{3}^{-}$. In contrast to the overlapping $\delta^{15} \mathrm{~N}$ for different $\mathrm{NO}_{3}^{-}$sources, $\delta^{18} \mathrm{O}$ and or $\Delta^{17} \mathrm{O}$ provide a clear separation between soil and atmospheric $\mathrm{NO}_{3}^{-}$sources. The $\delta^{18} \mathrm{O}$ of soil $\mathrm{NO}_{3}^{-}$produced by nitrification is distinctly lower (mean $=-4.0 \%$; -7.3 to $-0.9 \%$; Fang et al., 2012) than that of atmospheric $\mathrm{NO}_{3}^{-}(60-100 \%)$. The latter has high $\Delta^{17} \mathrm{O}$ values (around 25\%0) in contrast to $0 \%$ of soil-derived $\mathrm{NO}_{3}^{-}$(Kendall et al., 2007; Michalski, 2010; Costa et al., 2011) (Figure 5).

The process of $\mathrm{NO}_{3}^{-}$entry into root cells and subsequent transport processes within plants per se cause no isotope effect because of the lack of bond breakage. However, the acquisition of $\mathrm{NO}_{3}^{-}$ through mycorrhizae to root cells potentially causes an isotopic difference between tissue $\mathrm{NO}_{3}^{-}$in roots and $\mathrm{NO}_{3}^{-}$in soil. Root $\mathrm{NO}_{3}^{-}$may be enriched in heavier isotopes relative to soil $\mathrm{NO}_{3}^{-}$ if the $\mathrm{NO}_{3}^{-}$has experienced reduction during the $\mathrm{N}$ assimilation of mycorrhizae associated with the roots. Mycorrhizal fungi have substantial $\mathrm{NO}_{3}^{-}$reduction capacity (Ho and Trappe, 1975), but the fungal NR is present only in the presence of $\mathrm{NO}_{3}^{-}$and absence of $\mathrm{NH}_{4}^{+}$(Cove, 1966). So far, the isotopic effect of $\mathrm{NO}_{3}^{-}$ acquisition through mycorrhizae on tissue $\mathrm{NO}_{3}^{-}$in natural plants has not been estimated or differentiated. Pate et al. (1993) demonstrated that the bulk $\delta^{15} \mathrm{~N}$ differences between non-mycorrhizal and mycorrhizal species (with significant $\mathrm{NO}_{3}^{-}$storage and NRA) reflected the utilization of different $\mathrm{N}$ sources. There appears to be little or no isotopic discrimination within the plant during or subsequent to uptake of $\mathrm{NO}_{3}^{-}$. Mycorrhizal fungi are expected to show higher bulk $\delta^{15} \mathrm{~N}$ than available $\mathrm{N}$ sources [potentially including $\mathrm{NO}_{3}^{-}, \mathrm{NH}_{4}^{+}$, and DON (at least amino acids)] in soil and bulk $\mathrm{N}$ of host plants. However, the isotopic mechanism differed from that of tissue $\mathrm{NO}_{3}^{-}$and the isotope effect differed among mycorrhizal types (Högberg, 1997; Craine et al., 2009; Hobbie and Högberg, 2012). Högberg et al. (1999) showed that the ECM fungus had higher bulk $\delta^{15} \mathrm{~N}$ relative to the Pinus sylvestris plant, and the fractionation against ${ }^{15} \mathrm{~N}$ was smaller when $\mathrm{NO}_{3}^{-}$was the source than when $\mathrm{NH}_{4}^{+}$. It caused a marginal decrease in $\delta^{15} \mathrm{~N}$ of the $\mathrm{N}$ passing from the substrate through the fungus to the host, which is explained by the small size of the fungal $\mathrm{N}$ pool relative to the total $\mathrm{N}$ of the plant, i.e., the high efficiency of transfer (Emmerton et al., 2001; Hobbie and Högberg, 2012). The significant shift in $\delta^{15} \mathrm{~N}$ of fungal species was a function of fungal physiology; thus, it is difficult to constrain the $\mathrm{N}$ sources (using bulk $\delta^{15} \mathrm{~N}$ ) by mycorrhizal fungi or their plant partners in natural conditions (Emmerton et al., 2001).

The efflux of $\mathrm{NO}_{3}^{-}$from root to soil or the subsequent transport of $\mathrm{NO}_{3}^{-}$within plants is not expected to discriminate ${ }^{15} \mathrm{~N}$ as with the entry of soil $\mathrm{NO}_{3}^{-}$into root cells (Mariotti et al., 1982; Shearer et al., 1991). This can be attributed to that the diffusion of $\mathrm{NO}_{3}^{-}$through the membrane carriers of plant cells does not cause bonding breakage or consumption (Werner and Schmidt, 2002; Granger et al., 2004; Needoba et al., 2004). However, isotopic differences can occur between organs if partial $\mathrm{NO}_{3}^{-}$reduction occurs in roots before transportation. The transport of NR-processed $\mathrm{NO}_{3}^{-}$from roots to leaves might be misunderstood as isotopic fractionations of $\mathrm{NO}_{3}^{-}$transport or $\mathrm{NO}_{3}^{-}$reduction in shoots. So far, isotopic fractionations $(\varepsilon=$ $\left({ }^{\mathrm{l}} k /{ }^{\mathrm{h}} k-1\right) \times 1000$, where ${ }^{1} k$ and ${ }^{\mathrm{h}} k$ respectively stand for the reaction rate constants for lighter and heavier isotopes) during the reduction of $\mathrm{NO}_{3}^{-}$by $\mathrm{NR}$ in leaves were reported as $15 \%$ for

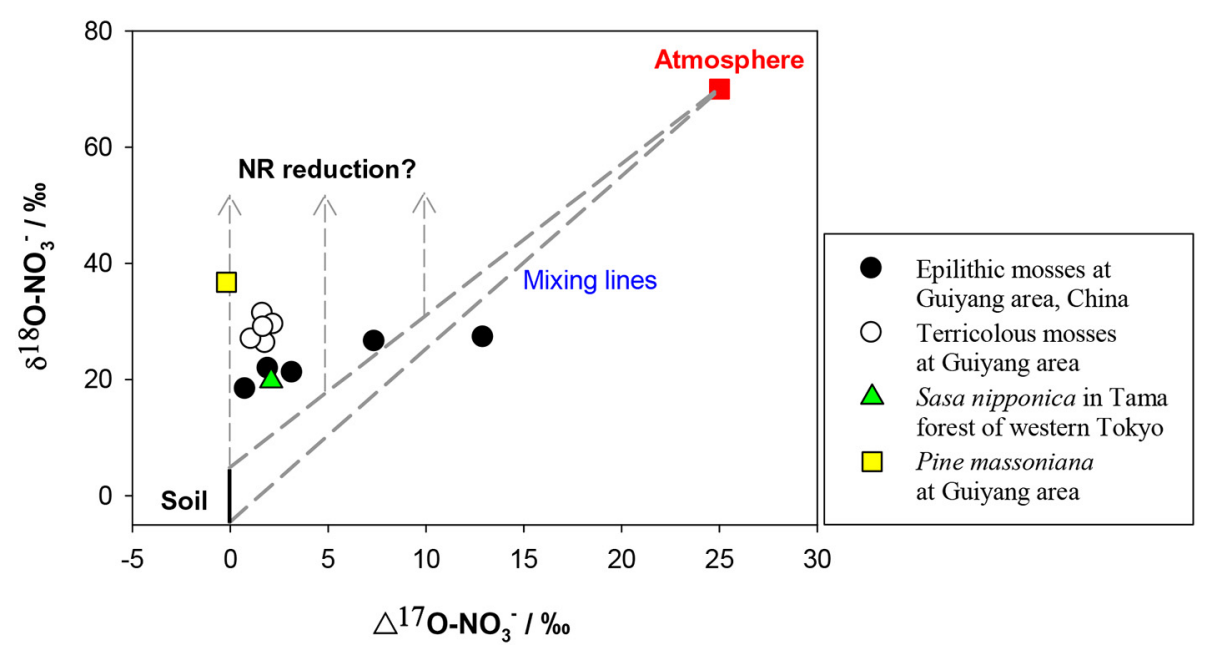

FIGURE 5 | Preliminary relation between $\delta^{18} \mathrm{O}$ and $\Delta^{17} \mathrm{O}$ values of $\mathrm{NO}_{3}^{-}$ in mosses and vascular plants. The $\delta^{18} \mathrm{O}$ and $\Delta^{17} \mathrm{O}$ values were considered respectively, as -5 to $5 \%$ and $0 \%$ for soil $\mathrm{NO}_{3}^{-}$(black and solid line), 70 and
$25 \%$ for atmospheric $\mathrm{NO}_{3}^{-}$(red square). Dashed lines show the isotopic range of mixing between atmospheric and soil sources. Dashed lines with arrows show the vectors of $\delta^{18} \mathrm{O}$ enrichments because of NR reduction. 
both $\mathrm{N}$ in spinach (Ledgard et al., 1985; Tcherkez and Farquhar, 2006) and O in wheat (Olleros-Izard, 1983) (Table 1). Direct measurement of endogenous $\mathrm{NO}_{3}^{-}$reduction in mosses after $\mathrm{N}$ deprivation showed similar values (Liu et al., 2012b) (Table 1). Although, NR isotopic fractionations have not been directly measured in roots, predictions can be made about the net enrichment of $\mathrm{NO}_{3}^{-}$isotopes in roots relative to those of soil $\mathrm{NO}_{3}^{-}\left(\Delta_{\text {root }}\right.$; expressed as $\delta_{\text {root }}-\delta_{\text {soil }}$ ). These values should be either negligible if substantial $\mathrm{NO}_{3}^{-}$reduction did not occur (Scenario 1; $\Delta_{\text {root }}=\delta_{\text {root }}-\delta_{\text {soil }} \approx 0$ ), or be close to the reported $\varepsilon$ values of NRA in leaves $\left(\varepsilon_{\mathrm{NR}}\right)(0-27 \%$; Table 1$)$ if $\mathrm{NO}_{3}^{-}$reduction occurred in the root (Scenario $2 ; \Delta_{\text {root }}=\delta_{\text {root }}-\delta_{\text {soil }} \approx \varepsilon_{\mathrm{NR}}>0$ ) (Figure 6). However, if the modification of soil $\mathrm{NO}_{3}^{-}$isotopes by soil microbial activities such as denitrification occurred later than root uptake, the observed isotopic values of root $\mathrm{NO}_{3}^{-}$can also be slightly lower than those of soil $\mathrm{NO}_{3}^{-}$despite reduction in roots (e.g., in the fine roots of a conifer investigated in Liu et al., 2013a). Furthermore, the variation of $\mathrm{NO}_{3}^{-}$isotopes with soil depth directly caused isotopic differences in initial $\mathrm{NO}_{3}^{-}$ sources available to co-existing plants with different root depths. Therefore, considering this fact, soil reference samples should be collected corresponding to root distribution for characterizing the soil $\mathrm{NO}_{3}^{-}$isotopes available to specific plants.

In a closed system, isotopic enrichment occurs with the enzymatic consumption of substrate $\mathrm{NO}_{3}^{-}$and $\varepsilon_{\mathrm{NR}}$ is expressed as $\Delta / \ln \left[\mathrm{NO}_{3}^{-}\right]_{\text {remaining }}$ fitted to the Rayleigh isotope fractionation model, where $\Delta$ represents the isotopic difference of remaining $\mathrm{NO}_{3}^{-}$from the initial $\mathrm{NO}_{3}^{-}\left(\delta_{\text {remaining }}-\delta_{\text {initial }}\right)$ (e.g., Granger et al., 2004, 2010). Isotopic enrichment also takes place for $\mathrm{NO}_{3}^{-}$remaining in plants after deprivation of $\mathrm{NO}_{3}^{-}$or $\mathrm{N}$ supply, because the tissue $\mathrm{NO}_{3}^{-}$pool is only changed by the NRA in a closed system (e.g., Liu et al., 2012b). Thus far, no experimental work has been done to explain the variability of ${ }^{18} \varepsilon_{\mathrm{NR}}$ in and among vascular plants. In $\mathrm{NO}_{3}^{-}$-supply studies, shoots tend to have higher $\delta^{15} \mathrm{~N}$ values because of the allocation of root NRprocessed $\mathrm{NO}_{3}^{-}$from roots to shoots (Kalcsits and Guy, 2013) or significantly higher ${ }^{15} \varepsilon_{\mathrm{NR}}$ (by 3.3-6.9\% ) than roots (Yoneyama and Kaneko, 1989; Evans et al., 1996; Yoneyama et al., 2001).
Evidence from marine biota showed that both ${ }^{15} \varepsilon_{\mathrm{NR}}$ and ${ }^{18} \varepsilon_{\mathrm{NR}}$ can vary with growing conditions and that significantly different $\varepsilon$ values exist among species (Table 1). In field conditions, $\mathrm{NO}_{3}^{-}$in an organ is more likely to be an open system with continuous source inputs (uptake), sinks (reduction), and outputs (translocation) (Figure 2). The uptake and allocation often occur according to the reduction ability and the distribution of NR, for example, a higher concentration and more NR are likely to exist in growing leaves (Gebauer et al., 1988; Cruz et al., 1991; Widmann et al., 1993). Passive or high accumulation as in mosses (Liu et al., 2012c) can happen in some organs such as conifer roots that are unable to reduce it (Liu et al., 2013a). Therefore, $\delta$ values of tissue $\mathrm{NO}_{3}^{-}$might not always follow the normal "Rayleigh type" relation, instead might increase with the increase in tissue $\left[\mathrm{NO}_{3}^{-}\right]$or show a non-significant correlation with $\left[\mathrm{NO}_{3}^{-}\right]$in the tissues (Liu et al., 2012c, 2013a). In fact, experimental studies have also shown the interplay of plant $\mathrm{NO}_{3}^{-}$uptake and reduction activity. The ${ }^{15} \mathrm{~N}$ discrimination during $\mathrm{NO}_{3}^{-}$assimilation in several higher plants was positively correlated with the supplied and tissue $\mathrm{NO}_{3}^{-}$concentrations, and negatively correlated with plant age (Kohl and Shearer, 1980; Mariotti et al., 1980, 1982; Bergersen et al., 1988; Liu et al., 2013a). Accordingly, the Rayleigh relation between $\mathrm{NO}_{3}^{-}$and its isotopes is not always applicable to examine $\varepsilon_{\mathrm{NR}}$ values and $\mathrm{NO}_{3}^{-}$reduction in organs of natural plants.

For some plants, $\mathrm{NO}_{3}^{-}$is not available in soil substrates. It can only be acquired from deposition (e.g., non-vascular plants or epiphytes). Alternatively, it is not available in deposition but can only be taken up from the soil (e.g., plants growing in arctic pristine ecosystems with negligible $\mathrm{NO}_{3}^{-}$deposition). In these plants, it is also feasible to diagnose leaf $\mathrm{NO}_{3}^{-}$reduction using $\Delta_{\text {leaf }}$ (the net enrichment of $\mathrm{NO}_{3}^{-}$isotopes in leaves relative to those of source $\mathrm{NO}_{3}^{-}$) (Scenarios 3-6; Figure 6).

Scenario 3: If no $\mathrm{NO}_{3}^{-}$was transported from soil to leaves, and leaf $\mathrm{NO}_{3}^{-}$if any, was completely derived from atmosphere, but no reduction occurred, then:

$$
\Delta_{\text {leaf }}=\delta_{\text {leaf }}-\delta_{\text {atm }} \approx 0 .
$$

Table 1 | Isotopic effects reported for $\mathrm{NO}_{3}^{-}$reduction $\left({ }^{*}\right.$ ) or net $\mathrm{NO}_{3}^{-}$assimilation in different biota.

\begin{tabular}{|c|c|c|c|}
\hline Biota & $15_{\varepsilon} / \%$ & $18_{\varepsilon} / \%$ & References \\
\hline Eukaryotic NR enzymes (from fungus and marine diatoms) & $26.6^{*}$ & $24.9 *$ & Karsh et al., 2012 \\
\hline Moss & $12.1^{*}$ & $14.4^{*}$ & Liu et al., 2012b \\
\hline Strains of prokaryotic plankton & $0.4-8.6$ & $0.9-8.1$ & Granger et al., 2010 \\
\hline Spinach and wheat & $15.0^{*}$ & $15.0 *$ & $\begin{array}{l}\text { Olleros-Izard, 1983; Ledgard et al., 1985; Tcherkez } \\
\text { and Farquhar, } 2006\end{array}$ \\
\hline Eukaryotic algae & $5.6-20.4$ & $5.1-21.0$ & Granger et al., 2004 \\
\hline \multirow[t]{2}{*}{ Marine phytoplankton } & $2.7-15.2$ & - & Needoba and Harrison, 2004 \\
\hline & 4-9 (field) 2.2-6.2 (lab) & - & Needoba et al., 2003 \\
\hline Tomato & $11.3-12.9$ & - & Evans et al., 1996 \\
\hline Leafy vegetable & $14.2-18.1$ & - & $\begin{array}{l}\text { Yoneyama and Kaneko, 1989; Yoneyama et al., } \\
2003\end{array}$ \\
\hline Grasses & $0.0-3.3$ & - & Mariotti et al., 1982 \\
\hline Pearl Millet and soybeans & $0.0-9.5$ & - & Mariotti et al., 1980, 1982; Bergersen et al., 1988 \\
\hline Red clover & $1.7-6.5$ & - & Kohl and Shearer, 1980 \\
\hline
\end{tabular}




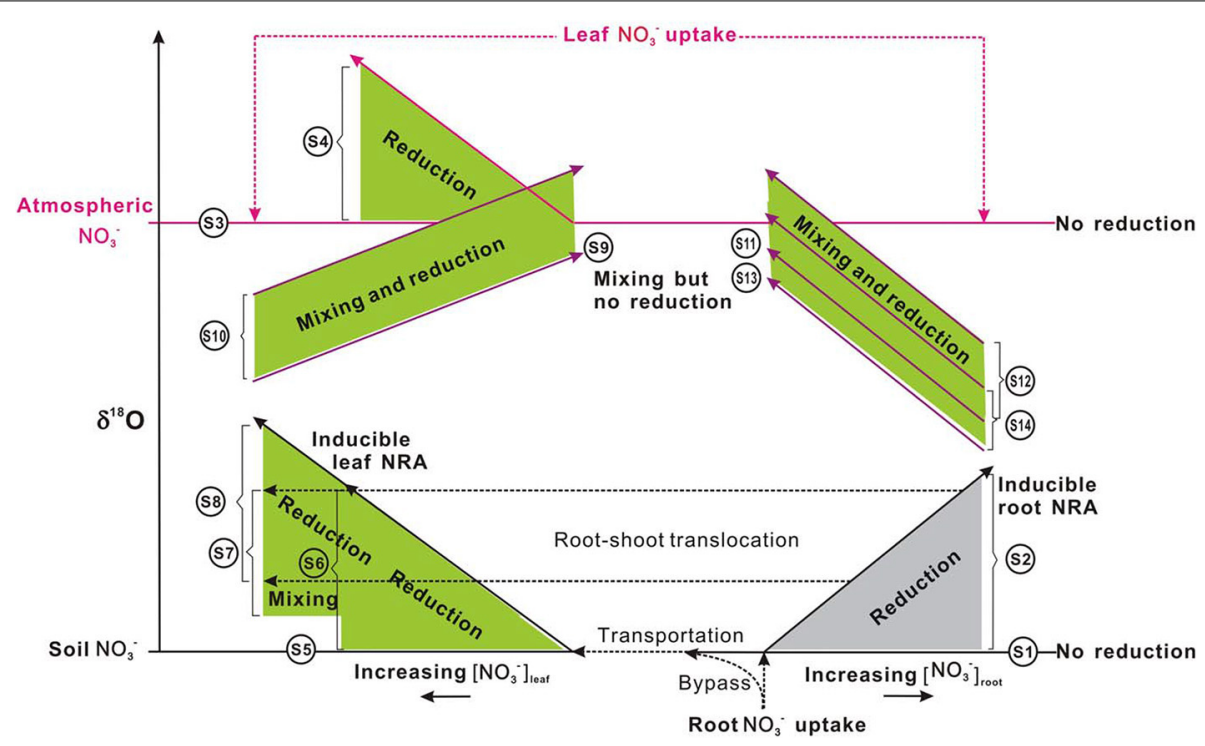

FIGURE 6 | Schematic showing $\delta^{18} \mathrm{O}-\mathrm{NO}_{3}^{-}$variations in plants under different uptake (from soil and or atmospheric sources: distinct in the $\delta^{18} \mathrm{O}$ value), translocation (from soil and or root to shoot), and reduction (potentially inducible by increasing $\left[\mathrm{NO}_{3}^{-}\right]$or no reduction and no isotopic enrichment with $\mathrm{NO}_{3}^{-}$accumulation, depending on species). Long and short solid lines with arrows respectively show the vectors of $\delta^{18} \mathrm{O}^{-} \mathrm{NO}_{3}^{-}$and $\left[\mathrm{NO}_{3}^{-}\right]$variations. Dashed lines with arrows show the uptake, transportation, and translocation of $\mathrm{NO}_{3}^{-}$from the soil to roots and or to leaves, from atmosphere to leaves, during which isotope effects were regarded as negligible. Shaded areas (gray for roots, green for leaves) show isotopic enrichment during the mixing of different sources (the $\delta^{18} \mathrm{O}^{-\mathrm{NO}_{3}^{-}}$in plants should be distributed between the $\delta^{18} \mathrm{O}$ values of sources, depending on the fraction of each source) and or the occurrence of NR reduction activities (the $\delta^{18} \mathrm{O}-\mathrm{NO}_{3}^{-}$in plants would be higher than the $\delta^{18} \mathrm{O}$ of sources but the magnitude of enrichment depends on in situ NR dynamics; presumably less than that presented in Table 1). For scenarios that occurred, leaf uptake of atmospheric $\mathrm{NO}_{3}^{-}$was assumed to be homogeneous. The shaded area, the spatial distance, and length of lines had no quantitative implications. S1-S12 correspond to scenarios 1-12 in the main text. Briefly,
$\mathrm{S} 1$, no occurrence of $\mathrm{NO}_{3}^{-}$reduction in roots; $\mathrm{S} 2$, (inducible) root $\mathrm{NO}_{3}^{-}$ reduction; $\mathrm{S} 3$, no $\mathrm{NO}_{3}^{-}$was transported from soil to leaves and leaf $\mathrm{NO}_{3}^{-}$was derived from the atmosphere, but no reduction occurred; $\mathrm{S} 4, \mathrm{no} \mathrm{NO}_{3}^{-}$was transported from soil to leaves and leaf $\mathrm{NO}_{3}^{-}$was from atmosphere and (inducible) reduction occurred; $\mathrm{S} 5$, leaf $\mathrm{NO}_{3}^{-}$was taken up directly from the soil, but no reduction occurred; $\mathrm{S} 6$, leaf $\mathrm{NO}_{3}^{-}$was taken up from the soil and reduction occurred therein; $\mathrm{S} 7$, leaf $\mathrm{NO}_{3}^{-}$is completely or partially transported from the root where it has experienced reduction, but no further reduction in the leaf; S8, leaf $\mathrm{NO}_{3}^{-}$is completely or partially transported from the root where it has experienced reduction, and is further reduced in the leaf; S9, leaf $\mathrm{NO}_{3}^{-}$was from both atmosphere and soil but no reduction occurred in the leaf; $\mathrm{S} 10$, leaf $\mathrm{NO}_{3}^{-}$was from both atmosphere and soil, and reduction occurred in the leaf; $\mathrm{S} 11$, leaf $\mathrm{NO}_{3}^{-}$is a mixture of atm- $\mathrm{NO}_{3}^{-}$and root $\mathrm{NO}_{3}^{-}$but no reduction occurred; $\mathrm{S} 12$, leaf $\mathrm{NO}_{3}^{-}$is a mixture of atm- $\mathrm{NO}_{3}^{-}$and root $\mathrm{NO}_{3}^{-}$, and reduction occurred in the leaf; $\mathrm{S}_{3}$, leaf $\mathrm{NO}_{3}^{-}$is a mixture of soil $\mathrm{NO}_{3}^{-}$, atm- $\mathrm{NO}_{3}^{-}$, and root $\mathrm{NO}_{3}^{-}$, but no reduction occurred in the leaf; $\mathrm{S} 14$, leaf $\mathrm{NO}_{3}^{-}$ is a mixture of soil $\mathrm{NO}_{3}^{-}$, atm- $\mathrm{NO}_{3}^{-}$, and root $\mathrm{NO}_{3}^{-}$, and reduction occurred in the leaf. The $\delta^{18} \mathrm{O}$ differences between $\mathrm{S} 13$ and $\mathrm{S} 11$, between $\mathrm{S} 12$ and $\mathrm{S} 14$ depend on the fraction of soil $\mathrm{NO}_{3}^{-}$in the mixed pool of leaves.
Scenario 4: If no $\mathrm{NO}_{3}^{-}$was transported from soil to leaves and leaf $\mathrm{NO}_{3}^{-}$was acquired from atmosphere; and reduction occurred, then:

$$
\Delta_{\text {leaf }}=\delta_{\text {leaf }}-\delta_{\text {atm }}>0
$$

Scenario 5: If all leaf $\mathrm{NO}_{3}^{-}$was taken up directly from the soil and no reduction occurred in roots or leaves, then:

$$
\Delta_{\text {leaf }}=\delta_{\text {leaf }}-\delta_{\text {soil }} \approx 0
$$

Scenario 6: If leaf $\mathrm{NO}_{3}^{-}$was transported completely from the soil and reduction occurred only in the leaves, then

$$
\Delta_{\text {leaf }}=\delta_{\text {leaf }}-\delta_{\text {soil }}>0
$$

The induction of $\mathrm{NR}$ by atmospheric-derived $\mathrm{NO}_{3}^{-}$has been shown in plants exposed to airborne $\mathrm{N}$ oxides (e.g., Norby et al., 1989; Wellburn, 1990). Scenarios 3-4 are expected to be true for mosses because atmospheric $\mathrm{NO}_{3}^{-}$has been assumed as the sole source (Liu et al., 2012a). Nevertheless, isotopic partitioning of $\mathrm{N}$ sources (Liu et al., 2013b) and further $\Delta^{17} \mathrm{O}$ analysis (Figure 5) suggests that moss $\mathrm{NO}_{3}^{-}$, even at epilithic habitats, is actually a mixture of atmospheric $\mathrm{NO}_{3}^{-}$and soil-derived $\mathrm{NO}_{3}^{-}$. Thus, it is becoming clear that mosses can acquire substantial $\mathrm{N}$ from substrates; and moss $\mathrm{NO}_{3}^{-}$is a valid atmospheric bio-monitor only for species growing on rare $\mathrm{N}$-free substrates. Scenarios 5-6 demonstrated $\mathrm{NO}_{3}^{-}$dynamics of vascular plants in the tundra of northern Alaska, where the $\Delta^{17} \mathrm{O}$ of $\mathrm{NO}_{3}^{-}$in plants with surprisingly high $\left[\mathrm{NO}_{3}^{-}\right]$was found as $0 \%$ (e.g., Polygonum bistorta). However, examining only $\Delta_{\text {leaf }}$ seems insufficient to determine $\mathrm{NO}_{3}^{-}$reduction location, since, isotopic enrichments of leaf $\mathrm{NO}_{3}^{-}$ might result from root reduction activities before moving up to leaves (Scenario 7).

Scenario 7: If the leaf $\mathrm{NO}_{3}^{-}$is completely or partly transported from the root where it has experienced reduction, but no reduction has occurred in the leaf; then an isotope mass-balance calculation can be conducted to quantify the amount of leaf $\mathrm{NO}_{3}^{-}$ 
accumulated directly from soil and indirectly from roots:

$$
\begin{aligned}
\Delta_{\text {root }} & =\delta_{\text {leaf }}-\delta_{\text {soil }} \approx \delta_{\text {root }}-\delta_{\text {soil }}>0, \\
\Delta_{\text {leaf }} & =\delta_{\text {leaf }}-\delta_{\text {root }}<0, \text { and } \\
\delta_{\text {leaf }} & =\left(1-f_{\text {root }}\right) \times \delta_{\text {soil }}+f_{\text {root }} \times \delta_{\text {root }} .
\end{aligned}
$$

The reduction of $\mathrm{NO}_{3}^{-}$that has experienced reduction in roots can further increase the isotopic enrichment of leaf $\mathrm{NO}_{3}^{-}$relative to soil $\mathrm{NO}_{3}^{-}$(Scenario 8) (Figure 6). This has been demonstrated by the $\delta^{15} \mathrm{~N}$ difference between roots and leaves in plants growing with $\mathrm{NO}_{3}^{-}$with known $\delta^{15} \mathrm{~N}$ values (Yoneyama and Kaneko, 1989; Evans et al., 1996; Yoneyama et al., 2001). This $\mathrm{NO}_{3}$ reduction occurs especially in plants that are capable of reducing $\mathrm{NO}_{3}^{-}$in both shoots and roots (Stewart et al., 1992).

Scenario 8: If the leaf $\mathrm{NO}_{3}^{-}$is completely or partially transported from roots where it has experienced reduction; and if it is further reduced in the leaf. In this case, a partitioning similar to scenario 7 can be done by considering the $\Delta_{\text {leaf }}$ in the isotope mass-balance calculation:

$$
\begin{aligned}
\Delta_{\text {root }} & =\delta_{\text {root }}-\delta_{\text {soil }}>0 \text { and } \\
\delta_{\text {leaf }} & =\left[\left(1-f_{\text {root }}\right) \times \delta_{\text {soil }}+f_{\text {root }} \times \delta_{\text {root }}\right]+\Delta_{\text {leaf }} .
\end{aligned}
$$

Plant $\mathrm{NO}_{3}^{-}$in scenarios 1-8 was derived either from the soil or atmosphere (Figure 6). A supplemental diagnosis of NR dynamics was to examine the covariance of $\Delta \delta^{18} \mathrm{O}: \Delta \delta^{15} \mathrm{~N}$ ratios $(\Delta$ is the isotopic enrichment of plant $\mathrm{NO}_{3}^{-}$relative to source $\mathrm{NO}_{3}^{-}$; $\left.\Delta=\delta_{\text {plant }}-\delta_{\text {source }}\right)$. This diagnosis helped determine whether the $\mathrm{N}-\mathrm{O}$ bond breakage attributable to $\mathrm{NO}_{3}^{-}$reduction was the single process driving $\mathrm{NO}_{3}^{-}{ }^{15} \mathrm{~N}$ and ${ }^{18} \mathrm{O}$ enrichments. Theoretically, the dissociation of an $\mathrm{O}$ atom from $\mathrm{NO}_{3}^{-}$predicted that $\mathrm{NO}_{3}^{-}$isotopes would be fractionated in an O-to-N ratio of ca. 0.6 (Brown and Drury, 1967). However, the NR often had the same O-to- $\mathrm{N}$ isotopic imprint on substrate $\mathrm{NO}_{3}^{-}$ in experimental studies. Consequently, the 1:1 trend was considered ubiquitous for biological $\mathrm{NO}_{3}^{-}$reduction (Granger et al., 2004, 2010). However, for leaves of vascular plants that acquire $\mathrm{NO}_{3}^{-}$from both atmosphere and soil, it is difficult to constrain leaf $\mathrm{NO}_{3}^{-}$reduction based only on the $\Delta_{\text {leaf }}\left(\delta_{\text {leaf }}-\delta_{\text {source }}\right)$ and $\varepsilon_{\mathrm{NR}}$, because the mixing of atmospheric $\mathrm{NO}_{3}^{-}$can raise the $\delta$ values (especially $\delta^{18} \mathrm{O}$ ). Liu et al. (2013a) observed that the $\delta^{18} \mathrm{O}: \delta^{15} \mathrm{~N}$ ratios in roots of a conifer generally followed the 1:1 rule; although leaf $\mathrm{NO}_{3}^{-}$showed distinctly higher $\delta^{18} \mathrm{O}: \delta^{15} \mathrm{~N}$ ratios (2.5:1) because of the mixing of atmospheric $\mathrm{NO}_{3}^{-}$.

As described above, the fraction of atmospheric-derived $\mathrm{NO}_{3}^{-}$ $\left(F_{\mathrm{atm}}\right)$ in leaves can be estimated using $\Delta^{17} \mathrm{O}$ mass-balance calculation $\left(F_{\text {atm }}=\Delta \Delta^{17} \mathrm{O}_{\text {leaf }} / \Delta^{17} \mathrm{O}_{\text {atm }}<1\right)$. Thereafter, the leaf $\mathrm{NO}_{3}^{-}$ sources and NR dynamics can be further constrained.

Scenario 9: If leaf $\mathrm{NO}_{3}^{-}$was absorbed from both the atmosphere and soil, but no reduction occurred in the leaf, then the fraction of atmospheric-derived $\mathrm{NO}_{3}^{-}$calculated using $\delta^{18} \mathrm{O}$ or $\delta^{15} \mathrm{~N}\left(f_{\text {atm }}\right)$ is expected to be similar to $F_{\text {atm }}$, as

$$
\begin{aligned}
& \delta_{\text {leaf }}=\left(1-f_{\text {atm }}\right) \times \delta_{\text {soil }}+f_{\text {atm }} \times \delta_{\mathrm{atm}}, \\
& \text { and } \quad f_{\text {atm }} \approx F_{\text {atm }}<1 .
\end{aligned}
$$

Scenario 10: If leaf $\mathrm{NO}_{3}^{-}$was absorbed from both the atmosphere and soil, and reduction occurred in the leaf, then:

$$
\begin{aligned}
\delta_{\text {leaf }} & =\left[\left(1-f_{\text {atm }}\right) \times \delta_{\text {soil }}+f_{\text {atm }} \times \delta_{\text {atm }}\right]+\Delta_{\text {leaf }}, \\
f_{\text {atm }} & \approx F_{\text {atm }}<1, \\
\text { and } \Delta_{\text {leaf }} & =\delta_{\text {leaf }}-\left[\left(1-F_{\text {atm }}\right) \times \delta_{\text {soil }}+F_{\text {atm }} \times \delta_{\text {atm }}\right]>0 .
\end{aligned}
$$

Scenario 11: If leaf $\mathrm{NO}_{3}^{-}$is a mixture of atm- $\mathrm{NO}_{3}^{-}$and $\operatorname{root} \mathrm{NO}_{3}^{-}$, but no reduction occurred, then:

$$
\begin{aligned}
\delta_{\text {leaf }} & =\left(1-f_{\mathrm{atm}}\right) \times \delta_{\text {root }}+f_{\mathrm{atm}} \times \delta_{\mathrm{atm}} \\
& \approx\left[\left(1-f_{\mathrm{atm}}\right) \times\left(\delta_{\text {soil }}+\Delta_{\text {root }}\right)+f_{\mathrm{atm}} \times \delta_{\mathrm{atm}}\right], \\
f_{\mathrm{atm}} & \approx F_{\mathrm{atm}}<1, \\
\text { and } \Delta_{\text {root }} & =\delta_{\text {root }}-\delta_{\text {soil }} \\
& \approx\left[\left(\delta_{\text {leaf }}-F_{\mathrm{atm}} \times \delta_{\mathrm{atm}}\right) /\left(1-F_{\mathrm{atm}}\right)\right]-\delta_{\text {soil }}>0
\end{aligned}
$$

Scenario 12: If leaf $\mathrm{NO}_{3}^{-}$is a mixture of atm- $\mathrm{NO}_{3}^{-}$and $\operatorname{root} \mathrm{NO}_{3}^{-}$; and if the reduction occurred in the leaf, then:

$$
\begin{aligned}
\delta_{\text {leaf }} & =\left[\left(1-f_{\text {atm }}\right) \times \delta_{\text {root }}+f_{\text {atm }} \times \delta_{\text {atm }}\right]+\Delta_{\text {leaf }} \\
& \approx\left[\left(1-f_{\text {atm }}\right) \times\left(\delta_{\text {soil }}+\Delta_{\text {root }}\right)+f_{\text {atm }} \times \delta_{\text {atm }}\right]+\Delta_{\text {leaf }}, \\
f_{\text {atm }} & \approx F_{\text {atm }}<1, \\
\Delta_{\text {root }} & =\delta_{\text {root }}-\delta_{\text {soil }}>0, \\
\text { and } \Delta_{\text {leaf }} & =\delta_{\text {leaf }}-\left[\left(1-f_{\text {atm }}\right) \times \delta_{\text {root }}+f_{\text {atm }} \times \delta_{\text {atm }}\right]>0 .
\end{aligned}
$$

Scenario 13: If leaf $\mathrm{NO}_{3}^{-}$is a mixture of soil $\mathrm{NO}_{3}^{-}$, atm- $\mathrm{NO}_{3}^{-}$, and root $\mathrm{NO}_{3}^{-}$, but no reduction occurred in the leaf, then:

$$
\begin{aligned}
& \delta_{\text {leaf }}=\left(1-f_{\text {atm }}-f_{\text {soil }}\right) \times \delta_{\text {root }}+f_{\text {atm }} \times \delta_{\text {atm }}+f_{\text {soil }} \times \delta_{\text {soil }}, \\
& f_{\text {atm }} \approx F_{\text {atm }}<1,
\end{aligned}
$$

and $\Delta_{\text {root }}=\delta_{\text {root }}-\delta_{\text {soil }}>0$.

Scenario 14: If leaf $\mathrm{NO}_{3}^{-}$is a mixture of soil $\mathrm{NO}_{3}^{-}$, atm- $\mathrm{NO}_{3}^{-}$, and root $\mathrm{NO}_{3}^{-}$, and if reduction occurred in the leaf, then:

$$
\begin{aligned}
\delta_{\text {leaf }}= & {\left[\left(1-f_{\text {atm }}-f_{\text {soil }}\right) \times \delta_{\text {root }}+f_{\text {atm }} \times \delta_{\text {atm }}\right.} \\
& \left.+f_{\text {soil }} \times \delta_{\text {soil }}\right]+\Delta_{\text {leaf }}, \\
f_{\text {atm }} \approx & F_{\text {atm }}<1, \\
\Delta_{\text {root }}= & \delta_{\text {root }}-\delta_{\text {soil }}>0, \\
\text { and } \Delta_{\text {leaf }}= & \delta_{\text {leaf }}-\left[\left(1-f_{\text {atm }}-f_{\text {soil }}\right) \times \delta_{\text {root }}\right. \\
& \left.+f_{\text {atm }} \times \delta_{\text {atm }}+f_{\text {soil }} \times \delta_{\text {soil }}\right]>0 .
\end{aligned}
$$

The parameters in the scenarios 9-14 $\left(f_{\text {atm }}, F_{\text {atm }}, \Delta_{\text {root }}, \Delta_{\text {leaf }}\right)$ above, provide theoretical constraints on possible $\mathrm{NO}_{3}^{-}$sources and reduction dynamics in leaves of field plants. As explained above, $\delta^{15} \mathrm{~N}$ values of $\mathrm{NO}_{3}^{-}$often overlapped for soil and atmospheric sources, although $\delta^{18} \mathrm{O}$ and or $\Delta^{17} \mathrm{O}$ can provide a clear differentiation between them (Kendall et al., 2007; Michalski, 
2010). Consequently, the scenarios above are better suited to the $\delta^{18} \mathrm{O}$ (depicted in Figure 6) than $\delta^{15} \mathrm{~N}$ analysis, particularly when leaf $\mathrm{NO}_{3}^{-}$was a mixing pool for different sources. The other solution to diagnose atmospheric $\mathrm{NO}_{3}^{-}$mixing and reduction is the $\Delta^{17} \mathrm{O}-\delta^{18} \mathrm{O}$ correlation, which has been used to trace $\mathrm{NO}_{3}^{-}$ sources and dynamics in aquatic environments (Tsunogai et al., 2011). Although preliminary, the $\Delta^{17} \mathrm{O}$ values in mosses showed clearly higher $F_{\text {atm }}$ than vascular plants, especially in epilithic mosses. Although, the $\Delta^{17} \mathrm{O}$ in terricolous mosses and vascular leaf samples was as low as $0.0-2.2 \%$, even at high $\mathrm{NO}_{3}^{-}$ concentration levels (Figure 5), suggesting a $0.0-8.8 \%$ of atmospheric contribution to leaf $\mathrm{NO}_{3}^{-}$pool. The NRA should be responsible for $\delta^{18} \mathrm{O}$ enrichment relative to the mixing values if plant-absorbed $\mathrm{NO}_{3}^{-}$has not been influenced by denitrification in soil. Such characterization cannot be warranted by correlation between $\delta^{15} \mathrm{~N}$ and $\delta^{18} \mathrm{O}$, or between tissue $\left[\mathrm{NO}_{3}^{-}\right.$] and isotopes (e.g., Liu et al., 2012c).

\section{UNCERTAINTIES IN TISSUE $\mathrm{NO}_{3}^{-}$-ISOTOPE METHODS AND FUTURE WORKS}

Although, the sampling time of plant materials can be controlled, diurnal and seasonal variations in tissue $\mathrm{NO}_{3}^{-}$and its isotopes should be verified in future works. Until now, no experimental work has directly examined NR enzymatic isotope kinetics in roots and leaves of higher plants. Moreover, it is difficult to mimic in situ NR isotope effects in field conditions. Isotope effects associated with $\mathrm{NO}_{3}^{-}$uptake and efflux remain unverified for roots. They were measured recently as $1-3 \%$ in growing cells of marine diatoms, and different $\mathrm{O}$ and $\mathrm{N}$ fractionations for both uptake and efflux were thought to cause the net ${ }^{18} \varepsilon:{ }^{15} \varepsilon$ of $\mathrm{NO}_{3}^{-}$assimilation above 1 (Karsh et al., 2014). The routes of transformation and entry of inorganic and organic $\mathrm{NO}_{3}^{-}$sources from the atmosphere into leaf cells and subsequent cellular actions have not been clarified, especially for non-aqueous processes. Consequently, the sources and supply rates of atmospheric $\mathrm{NO}_{3}^{-}$and their isotope signals should be explored further. Thus far, the $\Delta^{17} \mathrm{O}$ information of leaf $\mathrm{NO}_{3}^{-}$was sparse, and is mostly available for leaves with high $\mathrm{NO}_{3}^{-}$levels. It should be verified whether the atmospheric contribution is higher in low- $\left[\mathrm{NO}_{3}^{-}\right]$leaves or not. It is promising to measure $\mathrm{NO}_{3}^{-}$isotopes in xylem flow and twig samples for $\mathrm{NO}_{3}^{-}$transportation and translocation. Results of such studies can potentially provide useful insights into intraplant $\mathrm{NO}_{3}^{-}$ transportation and translocation, although the sampling methods of xylem flow are mostly destructive and in-twig $\mathrm{NO}_{3}^{-}$might be very low. For these reasons, more field works on tissue $\mathrm{NO}_{3}^{-}$at the organ, stand, and species levels should be done along with source isotope analysis. The scenarios proposed above provide the first conceptual constraint for both sources and $\mathrm{NO}_{3}^{-}$isotope effects in field plants. In conclusion, the concentration and isotopic analyses of $\mathrm{NO}_{3}^{-}$in plant tissues together provide new insights for elucidating plant $\mathrm{NO}_{3}^{-}$sources and strategies. These strategies will be valuable for exploring the communication of plant $\mathrm{N}$ utilization with environmental $\mathrm{N}$ pollution and altering ecosystem $\mathrm{N}$ cycles.

\section{ACKNOWLEDGMENTS}

This work was supported by a Grant for Projects for the Protection, Preservation and Restoration of Cultural Properties in
Japan by the Sumitomo Foundation, Grants-in-Aid for Creative Scientific Research (Nos. 21310008), the Program to Create an Independent Research Environment for Young Researchers from the Ministry of Education, Culture, Sports, Science and Technology, Japan, the NEXT Program (GS008) from the Japan Society for the Promotion of Science (JSPS), and JSPS KAKENHI Grant Number 26252020. Xue-Yan Liu was also supported by the National Natural Science Foundation of China (No. 41021062, 41273026) and the JSPS postdoctoral program for foreign researchers (No. 09F09316). We appreciate Drs. Muenoki Yoh, Lina Koyama, and Arata Mukotaka for the fruitful discussions.

\section{REFERENCES}

Aakra, Å., Hesselsøe, M., and Bakken, L. R. (2000). Surface attachment of ammonia-oxidizing bacteria in soil. Microbial. Ecol. 39, 222-235. doi: 10.1007/ s002480000006

Aber, J., McDowell, W., Nadelhoffer, K., Magill, A., Berntson, G., Kamakea, M., et al. (1998). Nitrogen saturation in temperate forest ecosystems: hypotheses revisited. Bioscience 48, 921-934. doi: 10.2307/1313296

Altieri, K., Hastings, M., Gobel, A., Peters, A., and Sigman, D. (2013). Isotopic composition of rainwater nitrate at Bermuda: the influence of air mass source and chemistry in the marine boundary layer. J. Geophys. Res. Atmos. 118, 304-311. doi: 10.1002/jgrd.50829

Alves, B. J. R., Zotarelli, L., Resende, A. S., Polidoro, J. C., Urquiaga, S., and Boddey, R. M. (2000). Rapid and sensitive determination of nitrate in plant tissue using flow injection analysis. Commun. Soil Sci. Plant Anal. 31, 2739-2750. doi: 10.1080/00103620009370623

Amberger, A., and Schmidt, H.-L. (1987). Natiirliche Isotopengehalte yon Nitrat als Indikatoren fiir dessen Herkunft. Geochim. Cosmochim. Acta. 51, 2699-2705. doi: 10.1016/0016-7037(87)90150-5

Anderson, K. A., and Case, T. E. (1999). Evaluation of plant nitrate extraction techniques and effect on commonly used analytical methods of detection. Commun. Soil. Sci. Plant Anal. 30, 1479-1495. doi: 10.1080/00103629909370301

Aslam, M. (1981). Reevaluation of anaerobic nitrite production as an index for the measurement of metabolic pool of nitrate. Plant Physiol. 68, 305-308. doi: 10.1104/pp.68.2.305

Atkin, O. K., Villar, R., and Cummings, W. R. (1993). The ability of several high arctic plant species to use nitrate nitrogen under field conditions. Oecologia 96, 239-245. doi: 10.1007/BF00317737

Beevers, L., and Hageman, R. H. (1969). Nitrate reduction in higher plants. Annu. Rev. Plant Physiol. 20, 495-522. doi: 10.1146/annurev.pp.20.060169.002431

Bergersen, F. J., Peoples, M. B., and Turner, G. L. (1988). Isotopic discriminations during the accumulation of nitrogen by soybeans. Aust. J. Plant Physiol. 15, 407-420. doi: 10.1071/PP9880407

Binnerup, S. J., and Sørensen, J. (1992). Nitrate and nitrite microgradients in barley rhizosphere as detected using a highly sensitive denitrification bioassay. Appl. Environ. Microb. 58, 2375-2380.

Bloom, A. J., Burger, M., Asensio, J. S. R., and Cousins, A. B. (2010). Carbon dioxide enrichment inhibits nitrate assimilation in wheat and Arabidopsis. Science 328, 899-903. doi: 10.1126/science.1186440

Bloom, A. J., Burger, M., Kimball, B. A., and Pinter, P. J. Jr. (2014). Nitrate assimilation is inhibited by elevated $\mathrm{CO}_{2}$ in field-grown wheat. Nat. Clim. Change 4, 477-480. doi: 10.1038/nclimate2183

Boudsocq, S., Niboyet, A., Lata, J. C., Raynaud, X., Loeuille, N., Mathieu, J., et al. (2012). Plant preference for ammonium versus nitrate: a neglected determinant of ecosystem functioning? Am. Nat. 180, 60-69. doi: 10.1086/665997

Britto, D. T., and Kronzucker, H. J. (2013). Ecological significance and complexity of $\mathrm{N}$-source preference in plants. Ann. Bot. 112, 957-963. doi: 10.1093/aob/mct157

Brown, L. L., and Drury, J. S. (1967). Nitrogen-isotope effects in the reduction of nitrate, nitrite, and hydroxylamine to ammonia. I In sodium hydroxide solution with Fe(II). J. Chem. Phys. 46, 2833-2837. doi: 10.1063/1.1841123

Campbell, W. H. (1999). Nitrate reductase structure, function and regulation: bridging the gap between biochemistry and physiology. Annu. Rev. Plant Physiol. 50, 277-303. doi: 10.1146/annurev.arplant.50.1.277

Cárdenas-Navarro, R., Adamowicz, S., and Robin, P. (1999). Nitrate accumulation in plants: a role for water. J. Exp. Bot. 50, 613-624. doi: 10.1093/jxb/50.334.613 
Casciotti, K. L., Sigman, D. M., Hasting, G. M., Böhlke, J. K., and Hilkert, A. (2002). Measurement of the oxygen isotopic composition of nitrate in seawater and freshwater using the denitrifier method. Anal. Chem. 74, 4905-4912. doi: 10.1021/ac020113w

Cernusak, L. A., Winter, K., and Turner, B. L. (2009). Plant $\delta^{15} \mathrm{~N}$ correlates with the transpiration efficiency of nitrogen acquisition in tropical trees. Plant Physiol. 151, 1667-1676. doi: 10.1104/pp.109.145870

Chapin, F. S. III. (1980). The mineral nutrition of wild plants. Annu. Rev. Ecol. Syst. 11, 233-260. doi: 10.1146/annurev.es.11.110180.001313

Chapin, F. S. III., Moilanen, L., and Kielland, K. (1993). Preferential use of organic nitrogen for growth by a non-mycorrhizal arctic sedge. Nature 361, 150-153. doi: $10.1038 / 361150 \mathrm{a} 0$

Christensen, S., and Tiedje, J. M. (1988). Sub-parts-per-billion nitrate methods: use of an $\mathrm{N}_{2} \mathrm{O}$-producing denitrifier to convert $\mathrm{NO}_{3}^{-}$or ${ }^{15} \mathrm{NO}_{3}^{-}$to $\mathrm{N}_{2} \mathrm{O}$. Appl. Environ. Microbiol. 54, 1409-1413. Available online at: http://aem.asm.org/ content/54/6/1409.abstract

Comstock, J. (2001). Steady-state isotopic fractionation in branched pathways using plant uptake of $\mathrm{NO}_{3}^{-}$as an example. Planta 214, 220-234. doi: $10.1007 / \mathrm{s} 004250100602$

Coplen, T. B. (2011). Guidelines and recommended terms for expression of stable-isotope-ratio and gas-ratio measurement results. Rapid. Commun. Mass Spectrom. 25, 2538-2560. doi: 10.1002/rcm.5129

Costa, A. W., Michalski, G., Alexander, B., and Shepson, P. B. (2011). Analysis of atmospheric inputs of nitrate to a temperate forest ecosystem from $\Delta^{17} \mathrm{O}$ isotope ratio measurements. Geophys. Res. Lett. 38, L15805. doi: 10.1029/2011GL047539

Cove, D. J. (1966). The induction and repression of nitrate reductase in the fungus Aspergillus nidulans. Biochim. Biophys. Acta. 113, 51-56. doi: 10.1016/S09266593(66)80120-0

Craine, J. M., Elmore, A. J., Aidar, M. P. M., Bustamante, M., Dawson, T. E., Hobbie, E. A., et al. (2009). Global patterns of foliar nitrogen isotopes and their relationships with climate, mycorrhizal fungi, foliar nutrient concentrations, and nitrogen availability. New Phytol. 183, 980-992. doi: 10.1111/j.14698137.2009.02917.x

Crawford, N. M. (1995). Nitrate: Nutrient and signal for plant growth. Plant Cell 7, 859-868. doi: 10.1105/tpc.7.7.859

Cruz, C. M., Soares, M. I. M., Martins-Loução, M. A., and Lips, S. H. (1991). Nitrate reduction in seedlings of carob (Ceratonia siliqua L.). New Phytol. 119, 413-419. doi: 10.1111/j.1469-8137.1991.tb00041.x

Elliott, E. M., Kendall, C., Boyer, E. W., Burns, D. A., Lear, G., Golden, H. E., et al. (2009). Dual nitrate isotopes in actively and passively collected dry deposition: utility for partitioning $\mathrm{NO}_{x}$ sources contributing to landscape nitrogen deposition. J. Geophys. Res. Biogeosci. 114:G04020. doi: 10.1029/2008JG000889

Emmerton, K. S., Callaghan, T. V., Jones, H. E., Leake, J. R., Michelsen, A., and Read, D. J. (2001). Assimilation and isotopic fractionation of nitrogen by mycorrhizal fungi. New Phytol. 151, 503-511. doi: 10.1046/j.1469-8137.2001.00178.x

Evans, R. D. (2001). Physiological mechanisms influencing plant nitrogen isotope composition. Trends Plant Sci. 6, 121-126. doi: 10.1016/S1360-1385(01)01889-1

Evans, R. D., Bloom, A. J., Sukrapanna, S. S., and Ehleringer, J. R. (1996). Nitrogen isotope composition of tomato (Lycopersicon esculentum Mill. cv. T-5) grown under ammonium or nitrate nutrition. Plant Cell Environ. 19, 1317-1323. doi: 10.1111/j.1365-3040.1996.tb00010.x

Fang, Y. T., Koba, K., Makabe, A., Zhu, F. F., Fan, S. Y., Liu, X. Y., et al. (2012). Low $\delta^{18} \mathrm{O}$ values of nitrate produced from nitrification in temperate forest soils. Environ. Sci. Technol. 46, 8723-8730. doi: 10.1021/es300510r

Felix, J. D., Elliott, E. M., and Shaw, S. (2012). The nitrogen isotopic composition of coal-fired power plant $\mathrm{NO}_{x}$ : the influence of emission controls and implications for global emission inventories. Environ. Sci. Technol. 46, 3528-3535. doi: $10.1021 /$ es203355v

Fenn, M. E., and Poth, M. A. (1998). "Indicators of nitrogen status in California forests," in Proceedings of the International Symposium on Air Pollution and Climate Change Effects on Forest Ecosystems, eds A. Bytnerowicz, M. Arbaugh, and S. Schilling (Riverside, CA: GTR-166).

Fenn, M. E., Poth, M. A., and Johnson, D. W. (1996). Evidence for nitrogen saturation in the San Bernardino Mountains in southern California. For. Ecol. Manage. 82, 211-230. doi: 10.1016/0378-1127(95)03668-7

Ferrari, T. E., and Varner, J. E. (1970). Control of nitrate reductase activity in barley aleurone layers. Proc. Natl. Acad. Sci. U.S.A. 65, 3, 729-736. doi: 10.1073/pnas.65.3.729
Gebauer, G., Melzer, A., and Rehder, H. (1984). Nitrate content in Rumex obtusifolius L. I. Differences in organs and diurnal changes. Oecologia 63, 136-142. doi: 10.1007/BF00379795

Gebauer, G., Rehder, H., and Wollenweber, B. (1988). Nitrate, nitrate reduction and organic nitrogen in plants from different ecological and taxonomic groups of Central Europe. Oecologia 75, 371-385. doi: 10.1007/BF00376940

Gessler, A., Rienks, M., and Rennenberg, H. (2002). Stomatal uptake and cuticular adsorption contribute to dry deposition of $\mathrm{NH}_{3}$ and $\mathrm{NO}_{2}$ to needles of adult spruce (Picea abies) trees. New Phytol. 156, 179-194. doi: 10.1046/j.14698137.2002.00509.x

Granger, J., Sigman, D. M., Needoba, J. A., and Harrison, P. J. (2004). Coupled nitrogen and oxygen isotope fractionation of nitrate during assimilation by cultures of marine phytoplankton. Limnol. Oceanogr. 49, 1763-1773. doi: 10.4319/lo.2004.49.5.1763

Granger, J., Sigman, D. M., Rohde, M. M., Maldonado, M. T., and Tortell, P. D. (2010). $\mathrm{N}$ and $\mathrm{O}$ isotope effects during nitrate assimilation by unicellular prokaryotic and eukaryotic plankton cultures. Geochim. Cosmochim. Acta 74, 1030-1040. doi: 10.1016/j.gca.2009.10.044

Haberhauer, G., and Blochberger, K. (1999). A simple cleanup method for the isolation of nitrate from natural water samples for $\mathrm{O}$ isotope analysis. Anal. Chem. 71, 3587-3590. doi: 10.1021/ac9814243

Hanson, P. J., and Garten, C. T. (1992). Deposition of $\mathrm{H}^{15} \mathrm{NO}_{3}$ vapour to white oak, red maple and loblolly pine foliage: experimental observations and a generalized model. New Phytol. 122, 329-337. doi: 10.1111/j.1469-8137.1992.tb04238.x

Harrison, K. A., Bol, R., and Bardgett, R. D. (2007). Preferences for different nitrogen forms by coexisting plant species and soil microbes. Ecology 88, 989-999. doi: $10.1890 / 06-1018$

Heaton, T. H. E. (1990). ${ }^{15} \mathrm{~N} /{ }^{14} \mathrm{~N}$ ratios of $\mathrm{NO}_{x}$ from vehicle engines and coal-fired power stations. Tellus 42, 304-307. doi: 10.1034/j.1600-0889.1990.00007.x-i1

Heaton, T. H. E., Spiro, B., and Roberston, S. M. C. (1997). Potential canopy influences on the isotopic composition of nitrogen and sulphur in atmospheric deposition. Oecologia 109, 600-660. doi: 10.1007/s004420050122

Hill, P. W., Marsden, K. A., and Jones, D. L. (2013). How significant to plant N nutrition is the direct consumption of soil microbes by roots? New Phytol. 199, 948-955. doi: 10.1111/nph.12320

Hipkin, C. R., Simpson, D. J., Wainwright, S. J., and Salem, M. A. (2004). Nitrification by plants that also fix nitrogen. Nature 430, 98-101. doi: 10.1038 /nature02635

Ho, I., and Trappe, J. M. (1975). Nitrate reducing capacity of two vesiculararbuscular mycorrhizal fungi. Mycologia 67, 886-888. doi: 10.2307/3758349

Hobbie, E. A., and Högberg, P. (2012). Nitrogen isotopes link mycorrhizal fungi and plants to nitrogen dynamics. New Phytol. 196, 367-382. doi: 10.1111/j.14698137.2012.04300.x

Högberg, P. (1997). ${ }^{15} \mathrm{~N}$ natural abundance in soil-plant systems. New Phytol. 137, 179-203. doi: 10.1046/j.1469-8137.1997.00808.x

Högberg, P., Högberg, M. N., Quist, M. E., Ekblad, A., and Näsholm, T. (1999). Nitrogen isotope fractionation during nitrogen uptake by ectomycorrhizal and non-mycorrhizal Pinus sylvestris. New Phytol. 142, 569-576. doi: 10.1046/j.14698137.1999.00404.x

Højberg, O., Johansen, H. S., and Sørensen, J. (1994). Determination of ${ }^{15} \mathrm{~N}$ abundance in nanogram pools of $\mathrm{NO}_{3}^{-}$and $\mathrm{NO}_{2}^{-}$by denitrification bioassay and mass spectrometry. Appl. Environ. Microb. 60, 2467-2472.

Houlton, B., Sigman, D., and Hedin, L. (2006). Isotopic evidence for large gaseous nitrogen losses from tropical rainforests. Proc. Natl. Acad. Sci. U.S.A. 103, 8745-8750. doi: 10.1073/pnas.0510185103

Imsande, J., and Touraine, B. (1994). N demand and the regulation of nitrate uptake. Plant Physiol. 105, 3-7.

Jones, M. E., Paine, T. D., and Fenn, M. E. (2008). The effect of nitrogen additions on oak foliage and herbivore communities at sites with high and low atmospheric pollution. Environ. Pollut. 151, 434-442. doi: 10.1016/j.envpol.2007.04.020

Kaiser, J., Hastings, M. G., Houlton, B. Z., Rockmann, T., and Sigman, D. M. (2007). Triple oxygen isotope analysis of nitrate using the denitrifier method and thermal decomposition of $\mathrm{N}_{2}$ O. Anal. Chem. 79, 599-607. doi: 10.1021/ ac061022s

Kalcsits, L. A., and Guy, R. D. (2013). Whole-plant and organ-level nitrogen isotope discrimination indicates modification of partitioning of assimilation, fluxes and allocation of nitrogen in knockout lines of Arabidopsis thaliana. Phys. Plant. 149, 249-259. doi: 10.1111/ppl.12038 
Karsh, K. L., Granger, J., Kritee, K., and Sigman, D. M. (2012). Eukaryotic assimilatory nitrate reductase fractionates $\mathrm{N}$ and $\mathrm{O}$ isotopes with a ratio near unity. Environ. Sci. Technol. 46, 5727-5735. doi: 10.1021/es204593q

Karsh, K. L., Trull, T. W., Sigman, D. M., Thompson, P. A., and Granger, J. (2014). The contributions of nitrate uptake and efflux to isotope fractionation during algal nitrate assimilation. Geochim. Cosmochim. Acta 132, 391-412. doi: 10.1016/j.gca.2013.09.030

Kendall, C., Elliott, E. M., and Wankel, S. D. (2007). “Tracing anthropogenic inputs of nitrogen to ecosystems," in Stable Isotopes in Ecology and Environmental Science, 2nd Edn., eds R. M. Michener and K. Lajtha (Oxford: Blackwell; Oxford Press), 375-449. doi: 10.1002/9780470691854.ch12

Koba, K., Hirobe, M., Koyama, L., Kohzu, A., Tokuchi, N., Nadelhoffer, K., et al. (2003). Natural N-15 abundance of plants and soil $\mathrm{N}$ in a temperate coniferous forest. Ecosystems 6, 457-469. doi: 10.1007/s10021-002-0132-6

Koba, K., Inagaki, K., Sasaki, Y., Takebayashi, Y., and Yoh, M. (2010a). "Nitrogen isotopic analysis of dissolved inorganic and organic nitrogen in soil extracts," in Earth, Life and Isotopes, eds N. Ohkouchi, I. Tayasu, and K. Koba (Kyoto: Kyoto University Press), 17-37.

Koba, K., Isobe, K., Takebayashi, Y., Fang, Y. T., Sasaki, Y., Saito, W., et al. (2010b). $\delta^{15} \mathrm{~N}$ of soil $\mathrm{N}$ and plants in a N-saturated, subtropical forest of southern China. Rapid Commun. Mass Spectrom. 24, 2499-2506. doi: 10.1002/rcm.4648

Koba, K., Tokuchi, N., Yoshioka, T., Hobbie, E., and Iwatsubo, G. (1998). Natural abundance of nitrogen-15 in a forest soil. Soil Sci. Soc. Amer. J. 62, 778-781. doi: 10.2136/sssaj1998.03615995006200030034x

Kohl, D. H., and Shearer, G. (1980). Isotopic fractionation associated with symbiotic $\mathrm{N}_{2}$ fixation and uptake of $\mathrm{NO}_{3}^{-}$by plants. Plant Physiol. 66, 51-56. doi: 10.1104/pp.66.1.51

Koyama, L., Hirobe, M., Koba, K., and Tokuchi, N. (2013). Nitrate-use traits of understory plants as potential regulators of vegetation distribution on a slope in a Japanese cedar plantation. Plant Soil 362, 119-134. doi: 10.1007/s11104-0121257-9

Kronzucker, H. J., Glass, A. D. M., and Siddiqi, M. Y. (1995). Nitrate induction in spruce: an approach using compartmental analysis. Planta 196, 683-690. doi: 10.1007/BF01106761

Lambers, H., Raven, J. A., Shaver, G. R., and Smith, S. E. (2008). Plant nutrientacquisition strategies change with soil age. Trends Ecol. Evolut. 23, 95-103. doi: 10.1016/j.tree.2007.10.008

Laursen, K. H., Mihailova, A., Kelly, S. D., Epov, V. N., Bérail, S., Schjoerring, J. K., et al. (2013). Is it really organic? Multi-isotopic analysis as a tool to discriminate between organic and conventional plants. Food Chem. 141, 2812-2820. doi: 10.1016/j.foodchem.2013.05.068

LeBauer, D. S., and Treseder, K. K. (2008). Nitrogen limitation of net primary productivity in terrestrial ecosystems is globally distributed. Ecology 89, 371-379. doi: 10.1890/06-2057.1

Ledgard, S. F., Woo, K. C., and Bergersen, F. J. (1985). Isotopic fractionation during reduction of nitrate and nitrite by extracts of spinach leaves. Aust. J. Plant Physiol. 12, 631-640. doi: 10.1071/PP9850631

Lensi, R., Gourbiere, F., and Josserand, A. (1985). Measurement of small amounts of nitrate in an acid soil by $\mathrm{N}_{2} \mathrm{O}$ production. Soil Biol. Biochem. 17, 733-734. doi: 10.1016/0038-0717(85)90056-2

Lexa, M., and Cheeseman, J. M. (1997). Growth and nitrogen relations in reciprocal grafts of wild-type and nitrate reductase-deficient mutants of pea (Pisum sativum L. var. Juneau). J. Exp. Bot. 48, 1241-1250. doi: 10.1093/jxb/ 48.6.1241

Liu, X. Y., Koba, K., Liu, C. Q., Li, X. D., and Yoh, M. (2012c). Pitfalls and new mechanisms in moss isotopic bio-monitoring of atmospheric nitrogen deposition. Environ. Sci. Technol. 46, 12557-12566. doi: 10.1021/es300779h

Liu, X. Y., Koba, K., Makabe, A., Li, X. D., Yoh, M., and Liu, C. Q. (2013b). Ammonium first: natural mosses prefer atmospheric ammonium but vary utilization of dissolved organic nitrogen depending on habitat and nitrogen deposition. New Phytol. 199, 407-419. doi: 10.1111/nph.12284

Liu, X. Y., Koba, K., Takebayashi, Y., Liu, C. Q., Fang, Y. T., and Yoh, M. (2012a). Preliminary insights into $\delta^{15} \mathrm{~N}$ and $\delta^{18} \mathrm{O}$ of nitrate in natural mosses: A new application of the denitrifier method. Environ. Pollut. 162, 48-55. doi: 10.1016/j.envpol.2011.09.029

Liu, X. Y., Koba, K., Takebayashi, Y., Liu, C. Q., Fang, Y. T., and Yoh, M. (2013a). Dual N and O isotopes of nitrate in natural plants: first insights into individual variability and organ-specific pattern. Biogeochemistry 114, 399-411. doi: 10.1007/s10533-012-9721-4
Liu, X. Y., Koba, K., Yoh, M., and Liu, C. Q. (2012b). Nitrogen and oxygen isotope effects of tissue nitrate associated with nitrate acquisition and utilization in the moss Hypnum plumaeforme. Funct. Plant Biol. 39, 598-608. doi: 10.1071/FP12014

Lockwood, A. L., Filley, T. R., Rhodes, D., and Shepson, P. B. (2008). Foliar uptake of atmospheric organic nitrates. Geophys. Res. Lett. 35:L15809. doi: 10.1029/2008GL034714

Mariotti, A., Germon, J. C., Hubert, P., Kaiser, P., Letolle, R., Tardieux, A., et al. (1981). Experimental determination of nitrogen kinetic isotope fractionation: some principles; illustration for the denitrification and nitrification processes. Plant Soil 62, 413-430. doi: 10.1007/BF02374138

Mariotti, A., Mariotti, F., Amarger, N., Pizelle, G., Ngambi, J., Champigny, M. L., et al. (1980). Eractionnements i.sotopiques de I'azoie lors des processus d'absorption des nitrates el de fixation de I'azote atmospherique par les plantes. Phvsiologie Vegetale 18, 163-181.

Mariotti, A., Mariotti, F., Champigny, M. L., Amarger, N., and Moyse, A. (1982). Nitrogen isotope fractionation associated with nitrate reductaseactivity and uptake of $\mathrm{NO}_{3}^{-}$by pearl millet. Plant Physiol. 69, 880-884. doi: 10.1104/pp.69.4.880

McIlvin, M. R., and Casciotti, K. L. (2011). Technical updates to the bacterial method for nitrate isotopic analyses. Anal. Chem. 83, 1850-1856. doi: 10.1021/ac1028984

McKane, R. B., Johnson, L. C., Shaver, G. R., Nadelhoffer, K. J., Rastetter, E. B., Fry, B., et al. (2002). Resource-based niches provide a basis for plant species diversity and dominance in arctic tundra. Nature 415, 68-71. doi: 10.1038/415068a

Michalski, G. (2010). Purification procedure for $\delta^{15} \mathrm{~N}, \quad \delta^{18} \mathrm{O}, \quad \Delta^{17} \mathrm{O}$ analysis of nitrate. Int. J. Environ. Anal. Chem. 90, 586-590. doi: 10.1080/03067310902783593

Mihailova, A., Pedentchouk, N., and Kelly, S. D. (2014). Stable isotope analysis of plant-derived nitrate - novel method for discrimination between organically and conventionally grown vegetables. Food Chem. 154, 238-245. doi: 10.1016/j.foodchem.2014.01.020

Miller, A. J., and Smith, S. J. (1996). Nitrate transport and compartmentation in cereal root cells, J. Exp. Bot. 47, 843-854. doi: 10.1093/jxb/47.7.843

Min, X., Siddiqi, M. Y., Guy, R. D., Glass, A. D. M., and Kronzucker, H. J. (1998). Induction of nitrate uptake and nitrate reductase activity in trembling aspen and lodgepole pine. Plant Cell Environ. 21, 1039-1046. doi: 10.1046/j.13653040.1998.00340.x

Mukotaka, A. (2014). A Study of Nitrogen Oxides Dynamics Between Urban Atmosphere and the Phyllosphere Using Triple Oxygen Isotopes. $\mathrm{Ph} . \mathrm{D}$. Dissertation, Tokyo Institute of Technology, Tokyo, 2-47.

Nacry, P., Bouguyon, E., and Gojon, A. (2013). Nitrogen acquisition by roots: physiological and developmental mechanisms ensuring plant adaptation to a fluctuating resource. Plant Soil 370, 1-29. doi: 10.1007/s11104-013-1645-9

Nadelhoffer, K. J., Shaver, G., Fry, B., Johnson, L., and McKane, R. (1996). ${ }^{15} \mathrm{~N}$ natural abundances and $\mathrm{N}$ use by tundra plants. Oecologia 107, 386-394. doi: 10.1007/BF00328456

Näsholm, T., Kielland, K., and Ganeteg, U. (2009). Uptake of organic nitrogen by plants. New Phytol. 182, 31-48. doi: 10.1111/j.1469-8137.2008.02751.x

Needoba, J. A., and Harrison, P. J. (2004). Influence of low light and a light:dark cycle on $\mathrm{NO}_{3}^{-}$uptake, intracellular $\mathrm{NO}_{3}^{-}$, and nitrogen isotope fractionation by marine phytoplankton. J. Phycol. 40, 505-516. doi: 10.1111/j.15298817.2004.03171.x

Needoba, J. A., Sigman, D. M., and Harrison, P. J. (2004). The mechanism of isotope fractionation during algal nitrate assimilation as illuminated by the ${ }^{15} \mathrm{~N} /{ }^{14} \mathrm{~N}$ of intracellular nitrate. J. Phycol. 40, 517-522. doi: 10.1111/j.15298817.2004.03172.x

Needoba, J. A., Waser, N. A., Harrison, P. J., and Calvert, S. E. (2003). Nitrogen isotope fractionation in 12 species of marine phytoplankton during growth on nitrate. Mar. Ecol. Prog. Ser. 255, 81-91. doi: 10.3354/meps 255081

Norby, R. J., Weerasuriya, Y., and Hanson, P. J. (1989). Induction of nitrate reductase activity in red spruce needles by $\mathrm{NO}_{2}$ and $\mathrm{HNO}_{3}$ vapor. Can. J. For. Res. 19, 889-896. doi: 10.1139/x89-135

Norwitz, G., and Keliher, P. N. (1986). Study of organic interferences in the spectrophotometric determination of nitrite using composite diazotizationcoupling reagents: Analyst 111, 1033-1037. doi: 10.1039/an9861101033

Olleros-Izard, T. (1983). Kinetische Isotopeneffekte der Arginase und Nitratreduktase Reaktion: ein Betrag zur Aufkl"arung der entsprechenden Reaktionmechanismen. $\mathrm{Ph}$. D. thesis, Technischen Universität München, Freising-Weihenstephan. 
Pate, J. S., Stewart, G. R., and Unkovich, M. (1993). ${ }^{15} \mathrm{~N}$ natural abundance of plant and soil components of a Banksia woodland ecosystem in relation to nitrate utilization, life form, mycorrhizal status and Ns-fixing abilities of component species. Plant Cell Environ. 16, 365-373. doi: 10.1111/j.13653040.1993.tb00882.x

Peuke, A. D., Gessler, A., and Tcherkez, G. (2013). Experimental evidence for diel $\delta^{15} \mathrm{~N}$-patterns in different tissues, xylem and phloem saps of castor bean (Ricinus communis L.). Plant Cell Environ. 36, 2219-2228. doi: $10.1111 /$ pce. 12132

Prasad, S., and Chetty, A. A. (2008). Nitrate-N determination in leafy vegetables: Study of the effects of cooking and freezing. Food Chem. 106, 772-780. doi: 10.1016/j.foodchem.2007.06.005

Raven, J. A. (2003). Can plants rely on nitrate? Trends Plant Sci. 8, 314-315. doi: 10.1016/S1360-1385(03)00125-0

Raven, J. A., Wollenweber, B., and Handley, L. L. (1992). A comparison of ammonium and nitrate as nitrogen sources for photolithotrophs. New Phytol. 121, 19-32. doi: 10.1111/j.1469-8137.1992.tb01088.x

Raven, J. A., and Yin, Z. H. (1998). The past, present and future of nitrogenous compounds in the atmosphere, and their interactions with plants. New Phytol. 139, 205-219. doi: 10.1046/j.1469-8137.1998.00168.x

Robe, W. E., Griffiths, H., Sleep, D., and Quarmby, C. (1994). Nitrogen partitioning and assimilation: methods for the extraction, separation and mass spectrometric analysis of nitrate, amino acid and soluble protein pools from individual plants following ${ }^{15} \mathrm{~N}$ labelling. Plant Cell Environ. 17, 1073-1079. doi: 10.1111/j.1365-3040.1994.tb02031.x

Robinson, D. (2001). $\delta^{15} \mathrm{~N}$ as an integrator of the nitrogen cycle. Trends Ecol. Evolut. 16, 153-162. doi: 10.1016/S0169-5347(00)02098-X

Robinson, D., Handley, L. L., and Scrimgeour, C. M. (1998). A theory for ${ }^{15} \mathrm{~N} /{ }^{14} \mathrm{~N}$ fractionation in nitrate-grown vascular plants. Planta $205,397-406$. doi: $10.1007 /$ s004250050336

Scheible, W. R., Gonzalez-Fontes, A., Morcuende, R., Lauerer, M., Muller-Rober, B., Michel Caboche, M., et al. (1997b). Nitrate acts as a signal to induce organic acid metabolism and repress starch metabolism in tobacco. Plant Cell. 9, 783-798. doi: $10.1105 /$ tpc.9.5.783

Scheible, W. R., Lauerer, M., Schulze, E. D., Caboche, M., and Stitt, M. (1997a). Accumulation of nitrate in the shoot acts as signal to regulate shoot-root allocation in tobacco. Plant J. 11, 671-691. doi: 10.1046/j.1365-313X.1997.11040671.x

Scheurwater, I., Koren, M., Lambers, H., and Atkin, O. K. (2002). The contribution of roots and shoots to whole plant nitrate reduction in fast- and slow-growing grass species. J. Exp. Bot. 53, 1635-1642. doi: 10.1093/jxb/erf008

Schimel, J. P., and Bennett, J. (2004). Nitrogen mineralization: challenges of a changing paradigm. Ecology 85, 591-602. doi: 10.1890/03-8002

Shearer, G., Schneider, J. D., and Kohl, D. H. (1991). Separating the efflux and influx components of net nitrate uptake by Synechococcus-R2 under steady-state conditions. J. Gen. Microbiol. 137, 1179-1184. doi: 10.1099/00221287-137-5-1179

Sievering, H., Tomasewski, T., and Torizzo, J. (2007). Canopy uptake of atmospheric $\mathrm{N}$ deposition at a conifer forest: part I -canopy $\mathrm{N}$ budget, photosynthetic efficiency and net ecosystem exchange. Tellus B 59, 483-492. doi: 10.1111/j. 1600-0889.2007.00264.x

Sigman, D. M., Casciotti, K. L., Andreani, M., Barford, C., Galanter, M., and Böhlke, J. K. (2001). A bacterial method for the nitrogen isotopic analysis of nitrate in seawater and freshwater. Anal Chem. 73, 4145-4153. doi: 10.1021/ac010088e

Simon, J., Li, X. Y., and Rennenberg, H. (2014). Competition for nitrogen between European beech and sycamore maple shifts in favour of beech with decreasing light availability. Tree Physiol. 34, 49-60. doi: 10.1093/treephys/tpt112

Somers, D. A., Kuo, T. M., Kleinhofs, A., Warner, R. L., and Oaks, A. (1983). Synthesis and degradation of barley nitrate reductase. Plant Physiol. 72, 949-952. doi: 10.1104/pp.72.4.949

Sparks, J. P. (2009). Ecological ramifications of the direct foliar uptake of nitrogen. Oecologia 159, 1-13. doi: 10.1007/s00442-008-1188-6

Sparks, J. P., Monson, R. K., Sparks, K. L., and Lerdau, M. T. (2001). Leaf uptake of nitrogen dioxide $\left(\mathrm{NO}_{2}\right)$ in a tropical wet forest: implications for tropospheric chemistry. Oecologia 127, 214-221. doi: 10.1007/s004420000594

Stadler, J., and Gebauer, G. (1992). Nitrate reduction and nitrate content in ash trees (Fraxinus excelsior L.): distribution between compartments, site comparison and seasonal variation. Trees 6, 236-240. doi: 10.1007/BF00224342

Stams, A. J. M., and Schipholt, I. J. L. (1990). Nitrate accumulation in leaves of vegetation of a forested ecosystem receiving high amounts of atmospheric ammonium sulfate. Plant Soil 125, 143-145. doi: 10.1007/BF00010754
Stevens, C. J., Manning, P., van den Berg, L. J. L., de Graaf, M. C. C., Wamelink, G. W. W., Boxman, A. W., et al. (2011). Ecosystem responses to reduced and oxidised nitrogen inputs in European terrestrial habitats. Environ. Pollut. 159, 665-676. doi: 10.1016/j.envpol.2010.12.008

Stewart, G. R., Joly, C. A., and Smirnoff, N. (1992). Partitioning of inorganic nitrogen assimilation between the roots and shoots of cerrado and forest trees of contrasting plant communities of South East Brasil. Oecologia 91, 511-517. doi: 10.1007/BF00650324

Stewart, G. R., Pate, G. S., and Unkovich, M. (1993). Characteristics of inorganic nitrogen assimilation of plants in fire-prone Mediterranean-type vegetation. Plant Cell Environ. 16, 351-363. doi: 10.1111/j.1365-3040.1993. tb00881.x

Takebayashi, Y., Koba, K., Sasaki, Y., Fang, Y. T., and Yoh, M. (2010). The natural abundance of ${ }^{15} \mathrm{~N}$ in plant and soil-available $\mathrm{N}$ indicates a shift of main plant $\mathrm{N}$ resources to $\mathrm{NO}_{3}$ from $\mathrm{NH}_{4}$ along the $\mathrm{N}$ leaching gradient. Rapid Commun. Mass Spectrom. 24, 1001-1008. doi: 10.1002/rcm.4469

Tang, M. H., Porder, S., and Lovett, G. M. (2012). Species differences in nitrate reductase activity are unaffected by nitrogen enrichment in northeastern US forests. For. Ecol. Manage. 275, 52-59. doi: 10.1016/j.foreco.2012. 03.006

Taylor, P. G., and Townsend, A. R. (2010). Stoichiometric control of organic carbon-nitrate relationships from soils to the sea. Nature 464, 1178-1181. doi: 10.1038/nature08985

Tcherkez, G., and Farquhar, G. D. (2006). Viewpoint: Isotopic fractionation by plant nitrate reductase, twenty years later. Funct. Plant Biol. 33, 531-537. doi: 10.1071/FP05284

Teklemariam, T. A., and Sparks, J. P. (2004). Gaseous fluxes of peroxyacetyl nitrate (PAN) into plant leaves. Plant Cell Environ. 27, 1149-1158. doi: 10.1111/j.13653040.2004.01220.x

Tischner, R. (2000). Nitrate uptake and reduction in higher and lower plants. Plant Cell Environ. 23, 1005-1024. doi: 10.1046/j.1365-3040.2000.00595.x

Tsunogai, U., Daita, S., Komatsu, D. D., Nakagawa, F., and Tanaka, A. (2011). Quantifying nitrate dynamics in an oligotrophic lake using $\Delta^{17} \mathrm{O}$. Biogeosciences 8, 687-702. doi: 10.5194/bg-8-687-2011

Vallano, D. M., and Sparks, J. P. (2008). Quantifying foliar uptake of gaseous nitrogen dioxide using enriched foliar $\delta^{15} \mathrm{~N}$ values. New Phytol. 177, 946-955. doi: 10.1111/j.1469-8137.2007.02311.x

Vitousek, P. M., and Howarth, R. W. (1991). Nitrogen limitation on land and in the Sea: How can it occur? Biogeochemistry. 13, 87-115. doi: 10.1007/BF00002772

Volk, R. J., Pearson, C. J., and Jackson, W. A. (1979). Reduction of plant tissue nitrate to nitric oxide for mass spectrometric N analysis. Anal. Biochem. 97, 131-135. doi: 10.1016/0003-2697(79)90336-1

Wanek, W., and Zotz, G. (2011). Are vascular epiphytes nitrogen or phosphorus limited? A study of plant ${ }^{15} \mathrm{~N}$ fractionation and foliar $\mathrm{N}: \mathrm{P}$ stoichiometry with the tank bromeliad Vriesea sanguinolenta. New Phytol. 192, 462-470. doi: 10.1111/j.1469-8137.2011.03812.x

Wang, L., and Schjoerring, J. K. (2012). Seasonal variation in nitrogen pools and ${ }^{15} \mathrm{~N} /{ }^{13} \mathrm{C}$ natural abundances in different tissues of grassland plants. Biogeosciences 9, 1583-1595. doi: 10.5194/bg-9-1583-2012

Wang, Y. Y., Hsu, P. K., and Tsay, Y. F. (2012). Uptake, allocation and signaling of nitrate. Trends Plant Sci. 17, 458-467. doi: 10.1016/j.tplants.2012. 04.006

Wellburn, A. R. (1990). Why are atmospheric oxides of nitrogen usually phytotoxic and not alternative fertilizers? New Phytol. 115, 395-429. doi: 10.1111/j.14698137.1990.tb00467.x

Wellburn, A. R. (1998). Atmospheric nitrogenous compounds and ozone - is $\mathrm{NO}_{x}$ fixation by plants a possible solution? New Phytol. 139, 5-9. doi: 10.1046/j.14698137.1998.00178.x

Werner, R. A., and Schmidt, H. L. (2002). The in vivo nitrogen isotope discrimination among organic plant compounds. Phytochemistry 61, 465-484. doi: 10.1016/S0031-9422(02)00204-2

Widmann, K., Gebauer, G., Rehder, H., and Ziegler, H. (1993). Fluctuations in nitrate reductase activity, and nitrate and organic nitrogen concentrations of succulent plants under different nitrogen and water regimes. Oecologia 94, 146-152. doi: 10.1007/BF00317316

Yoneyama, T., Ito, O., and Engelaar, W. M. H. G. (2003). Uptake, metabolism and distribution of nitrogen in crop plants traced by enriched and natural ${ }^{15} \mathrm{~N}$ : progress over the last 30 years. Phytochem. Rev. 2, 121-132. doi: 10.1023/B: PHYT.0000004198.95836.ad 
Yoneyama, T., and Kaneko, A. (1989). Variations in the natural abundance of ${ }^{15} \mathrm{~N}$ in nitrogenous fractions of komatsuna plants supplied with nitraie. Plant Cell Physiol. 30, 957-962.

Yoneyama, T., Matsumaru, T., Usui, K., and Engelaar, W. M. H. G. (2001). Discrimination of nitrogen isotopes during absorption of ammonium and nitrate at different nitrogen concentrations by rice Oryza sativa L. plants. Plant Cell Environ. 24, 133-139. doi: 10.1046/j.1365-3040.2001.00663.x

Yoneyama, T., and Tanaka, F. (1999). Natural abundance of ${ }^{15} \mathrm{~N}$ in nitrate, ureides, and amino acids from plant tissues. Soil Sci. Plant Nutr. 45, 751-755. doi: 10.1080/00380768.1999.10415840

Zhen, R. G., Koyro, H. W., Leigh, R. A., Tomos, A. D., and Miller, A. J. (1991). Compartmental nitrate concentrations in barley root cells measured with nitrate-selective microelectrodes and by single-cell sap sampling. Planta 185, 356-361. doi: 10.1007/BF00201056

Zhen, R. G., and Leigh, R. A. (1990). Nitrate accumulation by wheat (Triticum aestivum) in relation to growth and tissue concentrations. Plant Soil 124, 157-160. doi: 10.1007/BF00009253
Conflict of Interest Statement: The authors declare that the research was conducted in the absence of any commercial or financial relationships that could be construed as a potential conflict of interest.

Received: 30 January 2014; accepted: 03 July 2014; published online: 23 July 2014. Citation: Liu X-Y, Koba K, Makabe A and Liu C-Q (2014) Nitrate dynamics in natural plants: insights based on the concentration and natural isotope abundances of tissue nitrate. Front. Plant Sci. 5:355. doi: 10.3389/fpls.2014.00355

This article was submitted to Plant Physiology, a section of the journal Frontiers in Plant Science.

Copyright (C) 2014 Liu, Koba, Makabe and Liu. This is an open-access article distributed under the terms of the Creative Commons Attribution License (CC BY). The use, distribution or reproduction in other forums is permitted, provided the original author(s) or licensor are credited and that the original publication in this journal is cited, in accordance with accepted academic practice. No use, distribution or reproduction is permitted which does not comply with these terms. 